\title{
Neuronal FceRla directly mediates ocular itch via IgE-immune complex in a mouse model of allergic conjunctivitis
}

\author{
Huan Cui ${ }^{1}$, Fan Liư ${ }^{2}$, Yehong Fang ${ }^{1}$, Tao Wang ${ }^{1}$, Bo Yuan ${ }^{1}$ and Chao Ma ${ }^{1}, 2,3^{*}$ (D)
}

\begin{abstract}
Background: Classical understanding of allergic conjunctivitis (ACJ) suggests that ocular itch results from a mast cell-dependent inflammatory process. However, treatments that target inflammatory mediators or immune cells are often unsatisfying in relieving the stubborn itch symptom. This suggests that additional mechanisms are responsible for ocular itch in ACJ. In this study, we aim to determine the role of neuronal FcERla in allergic ocular itch.

Methods: Calcium imaging was applied to observe the effect of IgE-immune complex in trigeminal neurons. Genomic FcERla knockout mice and adeno-associated virus (AAV) mediated sensory neuron FcERla knockdown mice were used in conjunction with behavioral tests to determine ocular itch. In addition, immunohistochemistry, Western blot and quantitative RT-PCR were used for in vitro experiments.

Results: We found that FcERla was expressed in a subpopulation of conjunctiva sensory neurons. IgE-IC directly activated trigeminal neurons and evoked acute ocular itch without detectible conjunctival inflammation. These effects were attenuated in both a global FcERla-knockout mice and after sensory neuronal-specific FcERla-knockdown in the mouse trigeminal ganglion. In an ovalbumin (OVA) induced murine ACJ model, FceRla was found upregulated in conjunctiva-innervating CGRP + sensory neurons. Sensory neuronal-specific knockdown of FcERla significantly alleviated ocular itch in the ACJ mice without affecting the immune cell infiltration and mast cell activation in conjunctiva. Although FceRla mRNA expression was not increased by lgE in dissociated trigeminal ganglion neurons, FceRla protein level was enhanced by lgE in a cycloheximide-resistance manner, with concordant enhancement of neuronal responses to IgE-IC. In addition, incremental sensitization gradually enhanced the expression of FcERla in small-sized trigeminal neurons and aggravated OVA induced ocular itch.
\end{abstract}

Conclusions: Our study demonstrates that FceRla in pruriceptive neurons directly mediates IgE-IC evoked itch and plays an important role in ocular itch in a mouse model of ACJ. These findings reveal another axis of neuroimmune interaction in allergic itch condition independent to the classical IgE-mast cell pathway, and might suggest novel therapeutic strategies for the treatment of pruritus in $\mathrm{ACJ}$ and other immune-related disorders.

Keywords: Ocular itch, Allergic conjunctivitis, FceRla, Sensory neuron

*Correspondence: machao@ibms.cams.cn

${ }^{1}$ Department of Human Anatomy, Histology and Embryology, Institute of Basic Medical Sciences, Neuroscience Center, Chinese Academy of Medical Sciences, School of Basic Medicine, Peking Union Medical College, Beijing, China

Full list of author information is available at the end of the article

\section{Introduction}

Allergic conjunctivitis (ACJ) which approximately afflicts $15-20 \%$ of the population worldwide actually contains a group of diseases affecting the ocular surface, including seasonal allergic conjunctivitis and perennial allergic conjunctivitis in an acute form, whereas vernal keratoconjunctivitis, atopic keratoconjunctivitis and giant 
papillary conjunctivitis in a chronic form [1]. Ocular itch is the pathognomonic symptom of ACJ, and significantly reduces the quality of patient's life [2]. Preclinical evidence indicated a direct contribution of IgE-activated mast cells to both the early phase reaction and late-phase inflammation during ACJ [3]. The action of mast celldriven pruritogens such as histamine and protease to pruriceptors is regarded as the classic peripheral mechanism of itch [4-7]. However, available treatments targeting mast cells and related inflammatory factors such as antihistamine, mast cell stabilizer and steroid are often unsatisfying for ocular itch symptom and/or exhibit adverse side effects [8-10]. Thus, additional mechanisms besides mast cell-associated inflammation probably contribute to ACJ itch, which remain largely unexplored.

The ACJ patients usually have an elevated antigenspecific immunoglobulin (Ig) level, especially IgE in the serum and tears $[11,12]$. IgE, a subtype of immunoglobulin associated with allergic diseases, is produced by $\mathrm{B}$ cells after immune rearrangement. IgE-immune complex (IgE-IC) formed by allergen and specific IgE can elicit anaphylactic reaction through challenging Fc-epsilon receptors (FceRs) [13-15]. Fc epsilon receptor I (FceRI), a high-affinity activating IgE receptor, is defined structurally as a tetrameric complex comprising an $\alpha$-subunit (FceRI $\alpha$, the IgE binding chain), a $\beta$-subunit (Fc\&RI $\beta$ ), and two $\gamma$-subunits (FceRI $\gamma$ ) [16-19]. FceRI $\alpha$ plays a central role in allergic diseases through linking IgE and responsive cells, such as mast cells and basophils $[15,20] . \beta$ and $\gamma$ subunits of FceRI contain conserved immunoreceptor tyrosine-based activation motifs (ITAMs) and transmit intracellular signaling. Omalizumab, the humanized monoclonal IgE antibody, neutralizes the free circulating IgE, thereby preventing the binding of IgE to FceRI [21]. Clinical evidence showed favorable effects of subcutaneous treatment with omalizumab on antihistamines and mast-cell stabilizers unresponsive Vernal Keratoconjunctivitis, including the ocular itch symptom [22]. Therefore, IgE-FceRI might give rise to $\mathrm{ACJ}$ itch in a mast cell and inflammation independent manner.

Although IgE-FceRI signaling has been suggested to serve as a critical element in ACJ pathogenesis, its potential role in ocular itch under ACJ conditions remains unclear. Moreover, the FceRI is also expressed in peripheral sensory neurons besides the immune cells, such as mast cells and basophils. This neuronal receptor is functional, since antigen application could directly induce neuronal activation after sensitized with antigen-specific IgE [23, 24]. According to our previous research, IgE-IC also activated a subpopulation of trigeminal ganglion (TG) neurons and FceRI might participate in allergic ocular itch based on pharmacological results [25]. However, the in vivo evidence that neuronal FceRI contributes to ocular itch has not been explored. No studies have addressed whether FceRI is expressed in conjunctiva sensory neurons or whether IgE-IC acts directly on conjunctiva pruriceptors through neuronal FceRI to induce ocular itch. In this study, we tested the hypothesis that IgE-IC contributes to ACJ conjunctiva itch through direct activation of neuronal FceRI.

\section{Materials and methods \\ Animals}

Adult male mice (20-25 g; 6-8 weeks) were used in this study. Mice were housed under a 12-h light/12-h dark cycle with ad libitum access to food and water. Wild type C57BL/6 mice were purchased from the National Institutes for Food and Drug Control in China. The $c$-Kit W-sh/W-sh, Mrgpra $^{\text {GFP-cre }}$, and Mrgpra $3^{\text {GFP-Cre }} ;$ ROSA $26^{\text {td- }}$ Tomato mice were provided by Dr. Xinzhong Dong of Johns Hopkins University [26, 27]. The Fcerla-deficient mice $\left(\right.$ Fcer1 $\left.^{-/-}\right)$were provided by Jing Wang of Institute of Basic Medical Sciences, Chinese Academy of Medical Sciences, Department of Pathophysiology, Peking Union Medical College [28].

\section{Sensitization and challenging of mice}

The construction of the ACJ model was performed following our previous study. Briefly, on day 0 , day 7 , and day 14, i.p. injection of $100 \mu \mathrm{g}$ ovalbumin (OVA, SigmaAldrich, St. Louis, MO, USA) plus $100 \mu$ Imject Alum (Thermo Scientific, Rockford, IL, USA) dissolved in $200 \mu \mathrm{l}$ of PBS. On day $21,5 \mu \mathrm{l}$ of OVA (1\% in PBS) was applied topically to the lower conjunctival sac of both sides to induce ocular allergy. For the control-treated mice, OVA was topically applied in the lower conjunctival sac without any sensitization. The video record was applied immediately as OVA instillation, and tissue collection was performed approximately $12 \mathrm{~h}$ after the OVA challenge.

For the incremental sensitization workflow, the mice were divided into four groups: Control, Sensitized 1w, Sensitized 2w, and Sensitized 3w, respectively. Sensitization was carried out as following procedures: For Sensitized $3 \mathrm{w}$ group, on day 0 , day 7 , and day 14, i.p. injection of $100 \mu \mathrm{g}$ OVA (Sigma-Aldrich, St. Louis, MO, USA) plus $100 \mu \mathrm{l}$ Imject Alum (Thermo Scientific, Rockford, IL, USA) dissolved in $200 \mu \mathrm{l}$ of PBS. Sensitized $1 \mathrm{w}$ and Sensitized $2 \mathrm{w}$ groups mice received sensitization once on day 0 and twice on day 0 and day 7 , respectively, while Control group did not receive any sensitization. The mice used for immunohistochemistry and Western blot were decapitated and taken the TG tissues 1 week after the last sensitization without challenge. For the behavioral test, $1 \%$ OVA in $5 \mu \mathrm{l}$ PBS or $5 \mu \mathrm{l}$ PBS was applied topically to both eyes to induce allergic conjunctivitis 1 week after 
the last sensitization. The operators for the above experiments were double-blind.

\section{Behavioral assays}

Behavioral tests for ocular itch were carried out following the methods described in previous publications $[25,29,30]$. Mice were placed in acrylic chambers $(13 \times 9 \times 40 \mathrm{~cm})$ in a sound-proof room without persons for 3 consecutive days to allow acclimation. For the acute itch model, the tested mice were manually restrained, and $5 \mu \mathrm{l}$ of regents (capsaicin, $5 \mu \mathrm{M}$ in PBS containing $0.1 \%$ Tween 20; histamine; IgE-IC, $1-50 \mu \mathrm{g} / \mathrm{ml}$ in $5 \mu \mathrm{l}$ PBS; IgE, $50 \mu \mathrm{g} / \mathrm{ml}$ in $5 \mu \mathrm{l}$ PBS; OVA, $100 \mathrm{mg} / \mathrm{ml}$ in $5 \mu \mathrm{l}$ PBS) were applied gently into the inferior conjunctival sac. Then, mice were returned to recording chambers and recorded with a high-resolution digital camera (SONY HANDYCAM HDR-PJ580E, Japan) for $15 \mathrm{~min}$ or $1 \mathrm{~h}$. A single scratching bout was defined as the animal lifting its hind paw, scratching the treated eyes. A wiping bout was defined as the animal lifting its forelimb, wiping the ocular area, and returning to its original start position [30].

For the sensitized mice, the OVA challenge was performed 7 days after the last sensitization. 1\% OVA in $5 \mu \mathrm{l}$ PBS was gently instilled into the inferior conjunctival sac. Afterwards, the challenged mice were immediately returned back to the recording chambers to film for $1 \mathrm{~h}$. The scratching and wiping bouts were separately counted as scored the video-recorded behavior. Each applied regent was previously prepared and then coded by a laboratory assistant and not the experimenter. The experimenter who injected the chemical was blinded to the code and thus the chemical injected, as was the observer who scored the video-recorded behavior.

\section{Retrograde labeling}

Wheat Germ Agglutinin (Alexa Fluor ${ }^{\mathrm{T} M} 350$ Conjugated WGA, Thermo Fisher Scientific, W11263; $2 \mu \mathrm{l}$ in PBS) was injected into the submucosa of the palpebral conjunctiva using an insulin syringe as anesthetized by isoflurane [29]. Tissue collections were performed 48-60 h after the injection.

\section{Preparation of IgE-immune complex}

IgE-IC was formed by incubating OVA $(48 \mu \mathrm{g} / \mathrm{ml})$ (Sigma-Aldrich, St. Louis, MO, USA) and mouse antiOVA IgE $(80 \mu \mathrm{g} / \mathrm{ml})$ (Acris Antibodies, Inc, Rockville, MD, USA) for one $h$ at $37^{\circ} \mathrm{C}$, and the IgE-IC was diluted to $1 \mu \mathrm{g} / \mathrm{ml}, 10 \mu \mathrm{g} / \mathrm{ml}, 50 \mu \mathrm{g} / \mathrm{ml}$ for the behavioral test. Meanwhile, IgE-IC was diluted to $0.1 \mu \mathrm{g} / \mathrm{ml}$ for calcium imaging use. The ratio of OVA and mouse anti-OVA IgE was 2:1. The storage buffer of all the antibodies was exchanged to PBS buffer using $\mathrm{Zeba}^{\mathrm{TM}}$ spin desalting columns (Thermo Scientific, Rockford, IL, USA) before application to avoid the possible toxic or non-specific effects of sodium azide [25].

\section{Trigeminal injection}

The trigeminal injection was performed following previous studies [31,32]. The shRNA targeting the sequence of mice FceRIa (Gene Bank Accession: NM_14125,

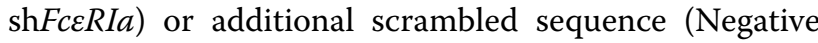
control, NC) was designed, respectively. Pirt promoter $(-2000$ to $+200 \mathrm{bp})$ was applied to guide the expression of shRNA in trigeminal sensory neurons. The recombinant adeno-associated virus type 9 (AAV9) containing Pirt promoter-guided shFceRIa sequence (AAV9-pirtshFceRIa-EGFP) or Pirt promoter-guided NC sequence (AAV9-pirt-NC-EGFP) was packaged using EGFP vector. The relative sequences are: $s h F c \varepsilon R I a, 5^{\prime}$-GCUAUGGGA ACAAUCACCUUCAAAU- $3^{\prime}$ and NC, $5^{\prime}$-TTC TCC GAA CGT GTC ACG T-3'. The adeno-associated virus $\left(1 \times 10^{12} \mathrm{TU}, 1 \mu \mathrm{l}\right)$ was injected into the trigeminal ganglion through the infraorbital foramen using a $30 \mathrm{G}$ needle. Two weeks after trigeminal injection, mice were used for relative experiments.

\section{Cell dissociation and culture}

Calcium imaging of cultured trigeminal ganglion neurons was performed as described previously [25]. TGs were harvested and transferred into the oxygenated complete saline solution (CSS) for cleaning and mincing. The TGs were then digested with Liberase TM (Roche, Basel, Switzerland) for $20 \mathrm{~min}$ and for another $10 \mathrm{~min}$ with Liberase TL (Roche, Basel, Switzerland) and papain (30U/ $\mathrm{ml}$; Worthington Biochemical, Lakewood, NJ, USA) in CSS containing $0.5 \mathrm{mM}$ EDTA at $37^{\circ} \mathrm{C}$. After enzymatic digestion, the cells were dissociated by gentle trituration with a fire-polished Pasteur pipette in a culture medium containing $0.5 \mathrm{mg} / \mathrm{ml}$ bovine serum albumin and $0.5 \mathrm{mg} /$ $\mathrm{ml}$ trypsin inhibitor and placed on poly-D-lysine/ laminin-coated 12-mm diameter circular glass coverslips. The culture medium contained equal amounts of DMEM and F12 with $10 \%$ FBS. The cells were maintained at $37{ }^{\circ} \mathrm{C}$ in a humidified atmosphere of $95 \%$ air and $5 \%$ $\mathrm{CO}_{2}$ and were used within $24 \mathrm{~h}$. Isotype $\mathrm{IgE}$ (ab37425, abcam) was added to the medium for $24 \mathrm{~h}$ to treat the dissociated neurons before the extraction of RNA or protein. Cycloheximide $(10 \mu \mathrm{g} / \mathrm{ml}, \mathrm{HY}-12320$, MedChemExpress), a potent inhibitor of translation, was added to the culture medium and treated the dissociated neurons for $24 \mathrm{~h}$ with or without IgE $(5 \mu \mathrm{g} / \mathrm{ml})$.

\section{Intracellular calcium imaging}

Intracellular calcium imaging was performed as described before [25]. Briefly, after loading Fura 2-acetoxy-methyl ester $(2 \mu \mathrm{M})$ in the dark for $45 \mathrm{~min}$ at $37^{\circ} \mathrm{C}$, 
TG neurons were placed in a recording chamber continuously perfused with HEPES buffer at a flow rate of $1.5 \mathrm{ml} /$ min at room temperature.

All reagents were dissolved in HEPES buffer and applied locally to the neuronal cell bodies through a micropipette (with a tip diameter of $100 \mu \mathrm{m}$ ). For the Mrgpra $3^{\text {GFP-Cre }}$ mouse line, we carried out the procedure to the cells that we detected GFP by fluorescence microscope. HEPES containing $1 \mu \mathrm{M}$ capsaicin or $50 \mathrm{mM} \mathrm{K}^{+}$ was used to confirm the responses to capsaicin and viability of neurons at the end of each experiment. Neurons were categorized according to the diameter of soma as small- $(<25 \mu \mathrm{m})$, medium- $(25-35 \mu \mathrm{m})$ and large-sized $(>35 \mu \mathrm{m})$.

\section{Immunohistochemistry}

Trigeminal ganglions from a male donor were obtained from the Brain Bank of Chinese Academy of Medical Science \& Peking Union Medical College, which had got informed consent for using the donated body tissue for medical research. The trigeminal ganglions were fixed in $10 \%$ formalin and then cryoprotected in $30 \%$ sucrose overnight. The tissue was sectioned at $10 \mu \mathrm{m}$ thick on a cryostat for the next immunohistochemistry experiment.

For mice receiving IgE-IC instillation, tissue collection was performed one after IgE-IC application, while tissue collection was performed approximately $12 \mathrm{~h}$ after OVA instillation for the ACJ model. All mice used for histology were anesthetized with pentobarbital sodium and transcardially perfused with ice-cold PBS followed by icecold 4\% PFA [29]. Tissues were post-fixed in ice-cold $4 \%$ PFA ( $6 \mathrm{~h}$ for conjunctiva; $1 \mathrm{~h}$ for TGs; $2 \mathrm{~h}$ for spleen) and cryoprotected in $30 \%(\mathrm{w} / \mathrm{v})$ sucrose for $24 \mathrm{~h}$ before they were embedded and frozen in OCT compound. The TGs and conjunctivas were sectioned at $10 \mu \mathrm{m}$ thick on a cryostat. After incubated with $10 \%$ normal horse serum for $1 \mathrm{~h}$, tissue sections were incubated at $4{ }^{\circ} \mathrm{C}$ overnight with primary antibodies. After being washed with PBS, sections were incubated with corresponding secondary antibodies for $1 \mathrm{~h}$ at room temperature. All antibodies used for immunohistochemistry are listed in Additional file 2: Table S1. For mast cell staining, tissue sections were incubated with FITC-conjugated avidin (Thermo Fisher Scientific, 434411) for $15 \mathrm{~min}$ at room temperature. After staining, tissue sections were mounted using fluorescent mounting medium (ZSGB-BIO, ZLI-9556, and ZLI$9557)$ and imaged after drying. Images were captured by a laser confocal microscopic imaging system (Olympus FV1000 and FluoView software). Neurons were classified as small- (area $\left.<442 \mu \mathrm{m}^{2}\right)$, medium- (area $443-865 \mu \mathrm{m}^{2}$ ), and large-sized (area $>865 \mu \mathrm{m}^{2}$ ) according to their crosssectional areas [33].

\section{Western blot}

Mouse TG tissues or dissociated TG neurons (cultured $24 \mathrm{~h}$ ) were harvested and homogenized in RIPA buffer (CW-bio, Beijing, China) with protease inhibitors (CWbio, Beijing, China). The homogenates were separated by SDS-PAGE gel and transferred to PVDF membranes. The membranes were incubated at $4{ }^{\circ} \mathrm{C}$ overnight by primary antibody (rabbit anti-FceRI $\alpha, 1: 1000$ and mouse anti- $\beta$-actin, $1: 2000)$ following incubated by $5 \%$ BSA for $1 \mathrm{~h}$. After incubated with the corresponding HRP-conjugated anti-IgG antibody (goat anti-rabbit IgG, 1:3000 and goat anti-mouse IgG, 1:3000), bands were determined using eECL Kit.

\section{Quantitative RT-PCR}

Total RNAs of cultured TG neurons were extracted by Trizol reagent (CW-bio, Beijing, China), which were reversely transcribed by RT Master Mix (Takara, Japan).

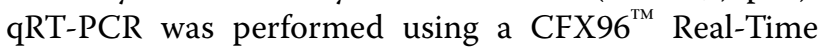
PCR Detection System (Bio-Rad, Hercules, California, USA) with SYBR premix Ex Taq ${ }^{\text {TM }}$ (Takara, Japan). The primers used were as follow: FceRI $\alpha$ Forward, 5'-GCT ATG GGA ACA ATC ACC TTC A-3' and Revers $5^{\prime}$-GGC ACT CAC AAT GAC CAA ATG T-3'; $\beta$-Actin Forward, 5'-GTC CCT CAC CCT CCC AAA AG-3' and Revers $5^{\prime}$-GCT GCC TCA ACA CCT CAA CCC-3'.

\section{Statistical analysis}

Data values were presented as means with standard errors (mean \pm SEM). Statistical analyses were performed using the SPSS software (version 17.0). A Student's $t$ test was used to evaluate the statistical significance of a difference between two groups. Comparisons for multiple groups or multiple timepoints were carried out using a 1-way or 2-way ANOVA for random measures or repeated measures followed by Bonferroni's post hoc test comparisons. Chi-square tests were used to compare between two or more incidence of events. The criterion for statistical significance was a value of $p<0.05$.

\section{Results \\ FcERla is expressed in mouse conjunctiva-innervating TG neurons}

First, immunofluorescence (IF) results showed that FceRIa was colocalized with neuronal marker PGP9.5 in trigeminal ganglion (TG), suggesting the expression of FceRI $\alpha$ in sensory neurons (Fig. 1A). Meanwhile, FceRI $\alpha$ expression was also detected in the PGP9.5-positive conjunctival nerve fiber (Fig. 1B). The effectiveness of the FceRI $\alpha$ antibody was validated by the lost IF signal in the TG and spleen of global $F c \varepsilon R I \alpha^{-/-}$mice. In addition, the specificity of the FceRI $\alpha$ antibody was verified by the lost 
IF signal in the TG as detected by the isotype IgG (Additional file 1: Fig. S1A-C). From a human TG, we found that FceRI $\alpha$ was expressed in sensory neurons with a percentage of $25.80 \%$ (89/345) (Fig. 1C, D). Furthermore, we performed double immunostaining to map the expression pattern of FceRI $\alpha$ in conjunctiva-innervating TG neurons that WGA retrogradely labeled. Among WGA-labeled conjunctiva sensory neurons, $48.91 \%$ of FceRI $\alpha^{+}$neurons coexpressed NF200, a marker for large-diameter neurons. In addition, 16.19\% of FceRI $\alpha^{+}$neurons coexpressed IB4, a nonpeptidergic nociceptive marker. Notably, 58.31\% of FceRIa ${ }^{+}$neurons coexpressed CGRP, a peptidergic nociceptive marker. However, no obvious colocalization of FceRIa protein expression with glutamine synthetase, a satellite glial cell marker, was detected (Fig. 1E). Using Mrgpra $3^{G F P-C r e}$ line, FceRI $\alpha$-positive trigeminal neurons colocalized with MrgprA3, a pruriceptor marker (Additional file 1: Fig. S1D, E). Moreover, the FceRI $\alpha$ signal was also detected in $\mathrm{MrpgrA}^{+}$conjunctival nerve fiber of Mrgpra ${ }^{\text {GFP-Cre }}$; ROSA26 ${ }^{\text {tdTomato }}$ mice (Additional file 1: Fig. S1F-H). These results imply that a subpopulation of conjunctiva sensory neurons, including nociceptors and pruriceptor, express FceRI $\alpha$, providing an anatomical basis for FceRI $\alpha$-mediated conjunctiva itch.

\section{IgE-IC directly activates TG neurons through FcERla}

To identify the effects of FceRI $\alpha$ expressed in TG sensory neurons on $\mathrm{Ca}^{2+}$ responses evoked by IgE-IC, we applied $\mathrm{Ca}^{2+}$ imaging in dissociated TG neurons from WT $\left(\right.$ Fcerla $\left.{ }^{+/+}\right)$and global FceRI $\alpha$ knockout $\left(F c e r 1 a^{-/-}\right)$ mice. We observed that IgE-IC responsive subpopulation was mainly small-diameter neurons $(65 / 68,95.59 \%)$ in $\mathrm{Fcer} \mathrm{a}^{+/+}$mice, one special character of nociceptors. In

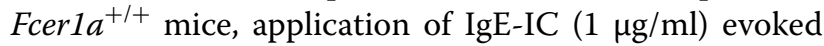
$\mathrm{Ca}^{2+}$ increases in $15.05 \%$ of small-diameter TG sensory neurons, the majority of which also reacted to capsaicin. Nevertheless, IgE-IC evoked $\mathrm{Ca}^{2+}$ responses in a significantly smaller fraction (1.60\%) of small-diameter TG neurons from Fcer $1 a^{-/-}$mice (Fig. 2). Using Mrgpra3 ${ }^{\text {GFP- }}$ ${ }^{C r e}$; ROSA26 $6^{\text {tdTomato }}$ mice, we detected $\mathrm{Ca}^{2+}$ responses in $\mathrm{MrgprA3}^{+}$neuron $(24 / 98,24.49 \%)$ as stimulated by IgEIC $(1 \mu \mathrm{g} / \mathrm{ml})$ (Additional file 1: Fig. S2). The above findings indicate that IgE-IC can directly activate TG sensory neurons in a FceRI $\alpha$-depended manner, which might be involved in ocular itch.

\section{Local instillation of IgE-IC elicits acute ocular itch} without obvious inflammation in naive mice

Since IgE-IC is able to stimulate immune cells and directly activate sensory neurons, IgE-IC was locally instilled in the conjunctiva to assess its effects on the inflammatory process and ocular itch (Fig. 3A). Ocular instillation of IgE-IC $(10 \mu \mathrm{g} / \mathrm{ml}$ and $50 \mu \mathrm{g} / \mathrm{ml})$, but not the vehicle (PBS), antigen $(100 \mathrm{mg} / \mathrm{ml}$ OVA in $\mathrm{PBS})$, or monomeric IgE, immediately induced eyetowards scratching behavior, one indicator for the ocular itch. In addition, this ocular itch could last to $3 \mathrm{~h}$ after IgE-IC application but could not be detected from $6 \mathrm{~h}$ (Fig. 3B). However, no significant difference was detected for the eye-towards wiping behavior, one indicator for ocular pain (Additional file 1: Fig. S3A). The H\&E staining for the conjunctivas did not detect any signs of immune cell infiltration at $1 \mathrm{~h}$ after instillation (Fig. 3C). To further investigate the effects of ocular instillation of IgE-IC on local immune status, we used immunofluorescence staining to assess cellular infiltration of neutrophils (marked by Ly6C/G), macrophages (marked by IBA1), and lymphocytes (marked by CD3) into the conjunctiva. One hour after ocular instillation, no significant differences were observed in any of these markers for mice receiving PBS, IgE, and IgE-IC treatment (Fig. 3D-H). We next examined the effects of IgE-IC instillation on infiltration and activation of mast cells. The numbers of mast cells within the conjunctiva sections (labeled by FITC-avidin) showed no difference in the IgE-IC instillation group compared with PBS and monomeric IgE. Meanwhile, the percentages of degranulated mast cells also showed no difference for the mice receiving IgE-IC instillation (Fig. 3I-K). In addition, we did not observe obvious immune cell infiltration (neutrophils, macrophages, and lymphocytes) within TG $1 \mathrm{~h}$ after instillation (Additional file 1: Fig. S3B-E). We detected mast cells within the TG tissue, while no obvious mast cells infiltration and activation were noted in TG from mice treated by PBS, IgE, and IgE-IC (Additional file 1: Fig. S3F-H). These results suggest that IgG-IC is sufficient to specifically evoke behavioral signs of acute ocular itch, but not pain, without detective immune cell infiltration and mast cell activation in conjunctiva and TG, at least at the early stages.

(See figure on next page.)

Fig. 1 Analysis of FceRla expression in conjunctiva-innervating sensory neurons. A Double-immunostaining showed that FceRla signal was colocalized with the neuronal marker PGP9.5 in the trigeminal ganglion of mice. Scale bar: $100 \mu \mathrm{m}$. B FceRla was detected in PGP9.5 neuronal fiber in the conjunctiva of mice. Scale bar: $25 \mu \mathrm{m}$. C Double-immunostaining showed that FceRla signal was colocalized with the neuronal marker PGP9.5 in the trigeminal ganglion of human. Scale bar: $100 \mu \mathrm{m}$. D Expression pattern of FceRla along different sizes trigeminal neurons in human trigeminal ganglion. E Fluorescent immunostaining in WGA-labeled (blue) TG for FcERla (green) and markers (red) including NF200 ( $n=4$ mice), IB4 ( $n=4$ mice), CGRP ( $n=4$ mice), and glutamine synthetase (GS; $n=4$ mice), along with quantitative analysis of percentage overlap. Scale bars: $100 \mu m$ 

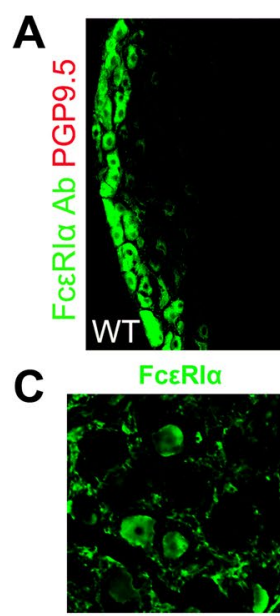

D

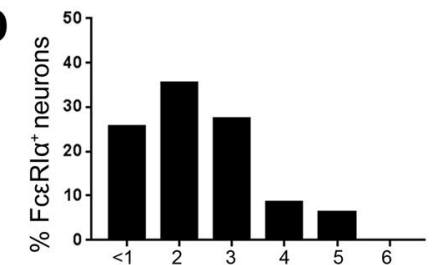

E
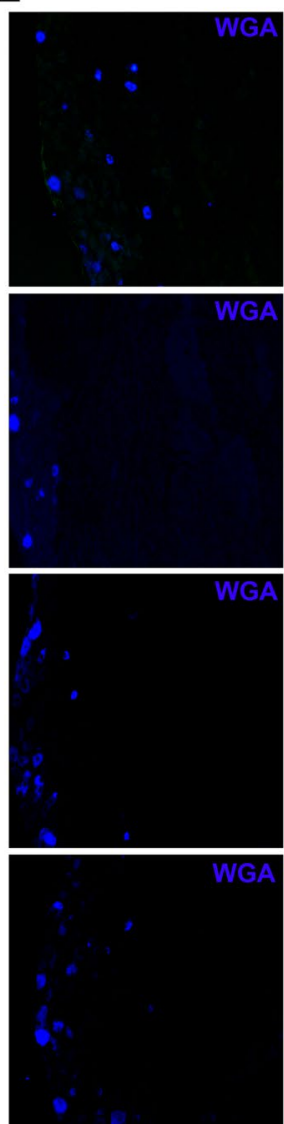

Fig. 1 (See legend on previous page.)
B
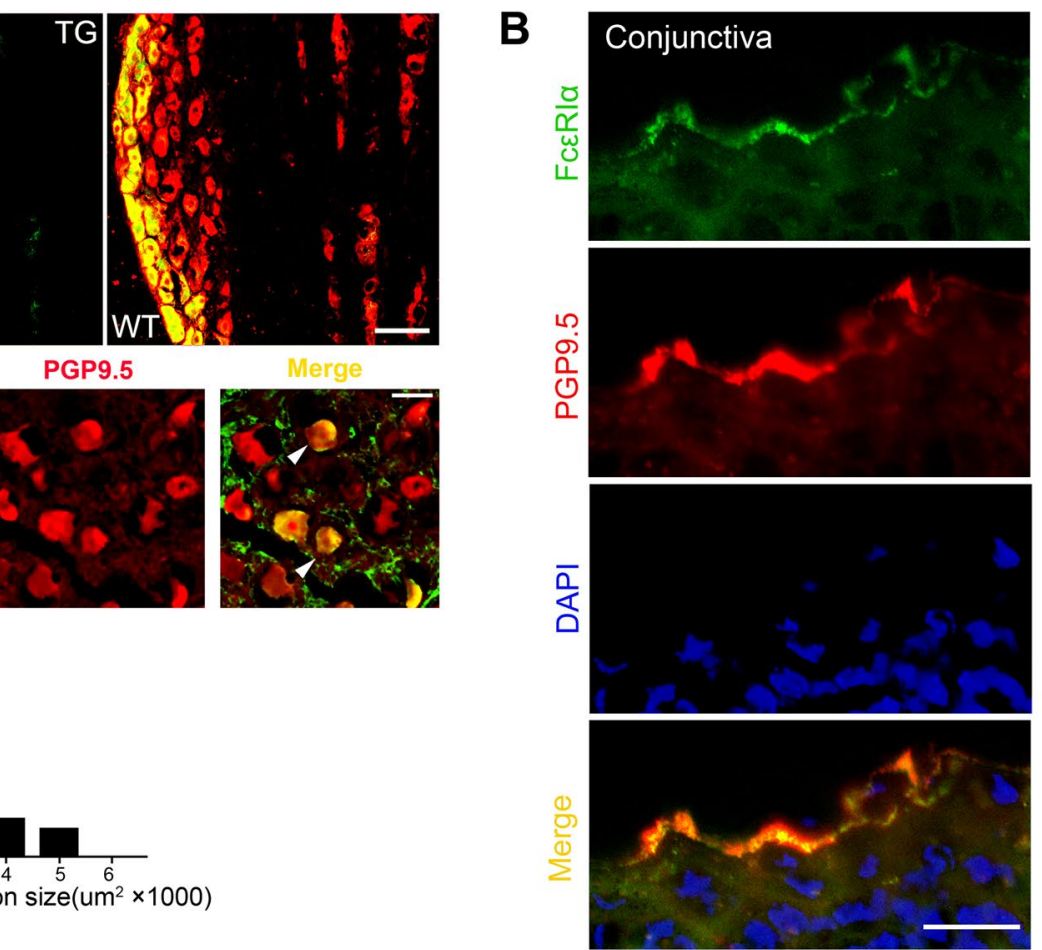

size $\left(u^{2} \times 1000\right)$
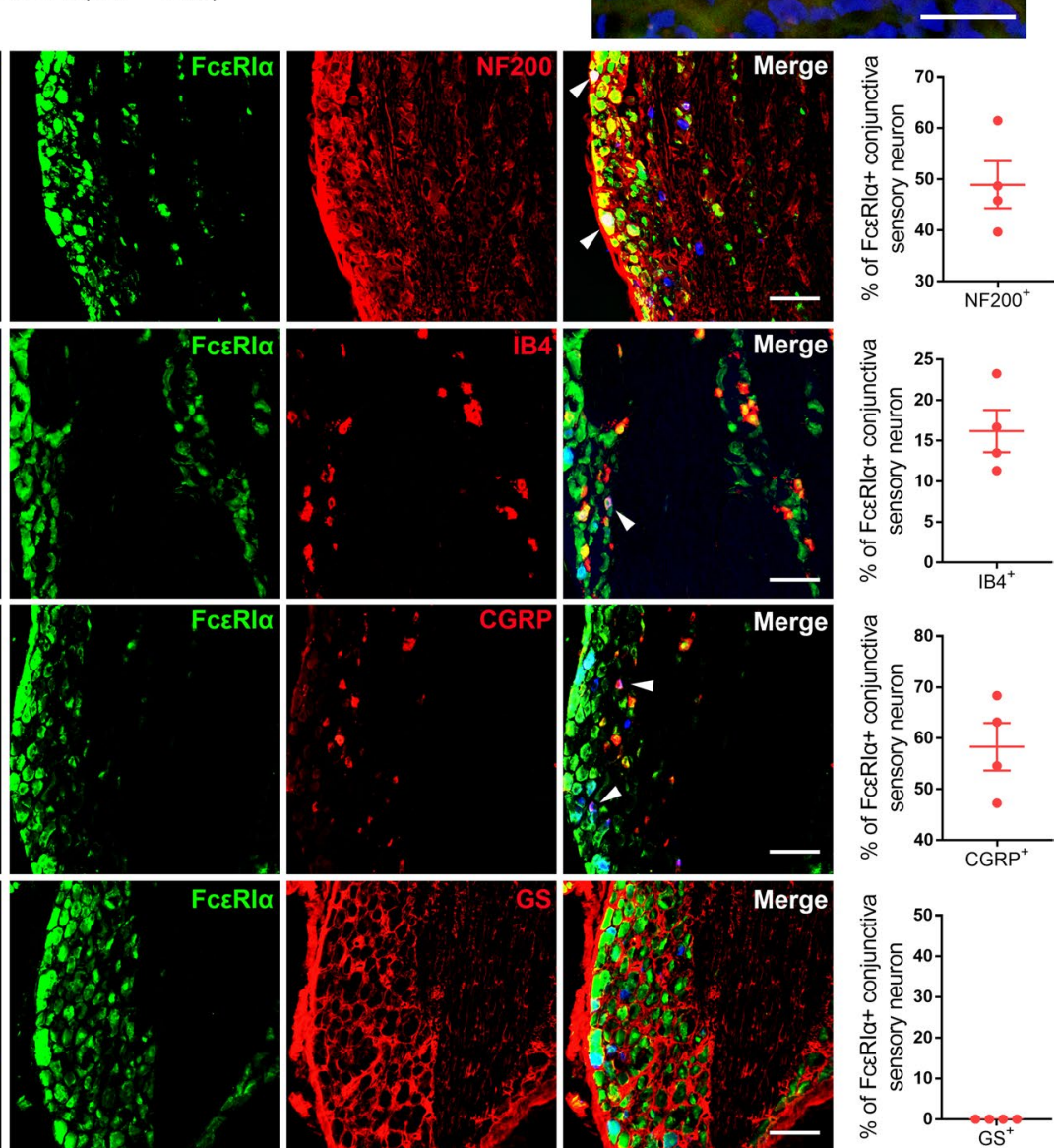

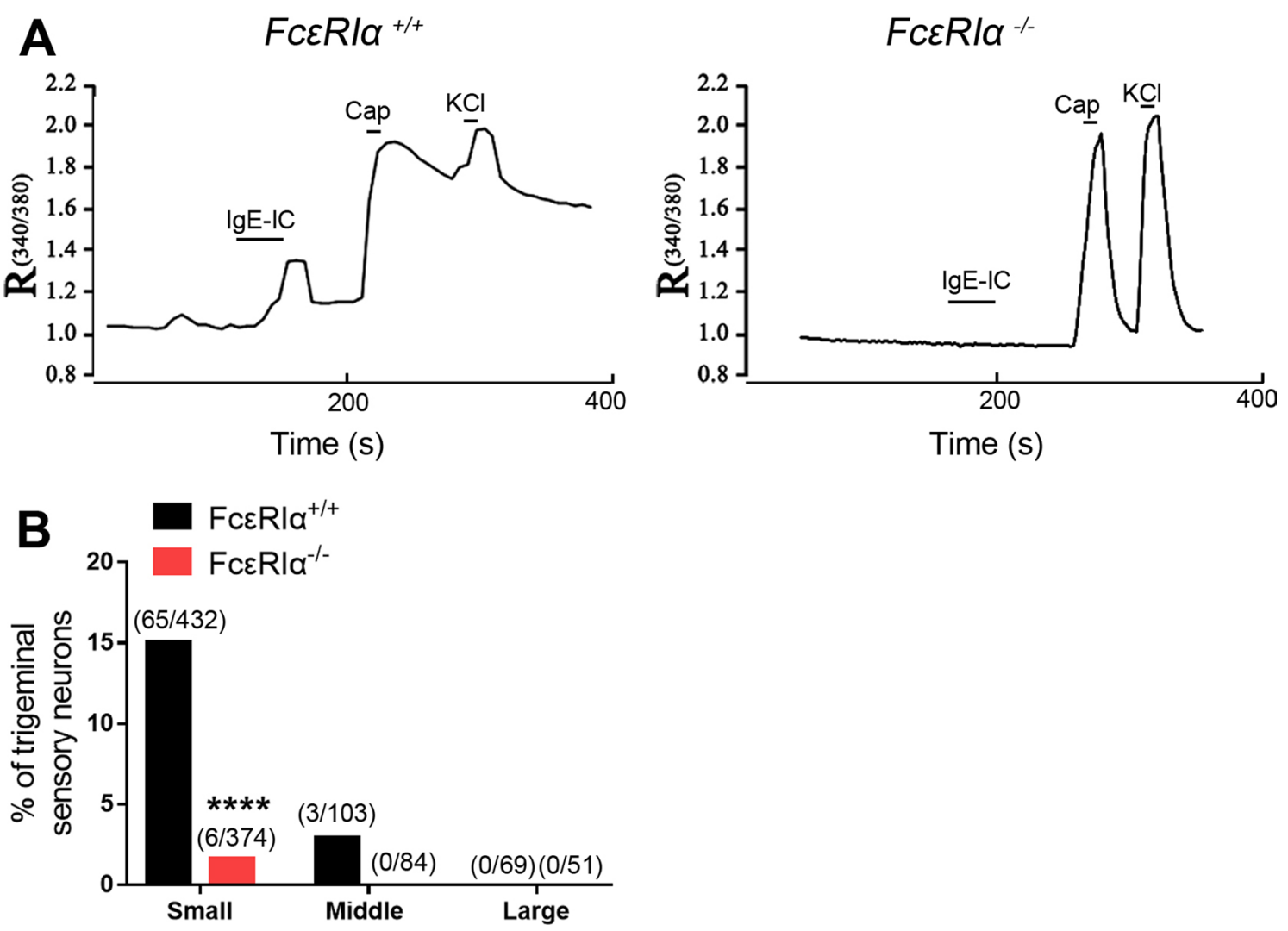

Fig. 2 IgE-IC directly activates trigeminal sensory neurons through FcERla in vitro. A Representative traces of Ca ${ }^{2+}$ responses induced by lgE-IC $(0.1 \mu \mathrm{g} / \mathrm{ml}, 30 \mathrm{~s})$, capsaicin $(\mathrm{Cap} ; 1 \mu \mathrm{M}, 10 \mathrm{~s})$, and $\mathrm{KCl}(50 \mathrm{mM}, 10 \mathrm{~s})$ in trigeminal neurons from FcER/a ${ }^{+/+}$(left) and global FcER/a ${ }^{-/-}$(right) mice. B Quantitative analysis showed that IgE-IC evoked $\mathrm{Ca} 2^{+}$responses in a larger proportion of small-diameter $(<25 \mu \mathrm{m})$ trigeminal neurons from

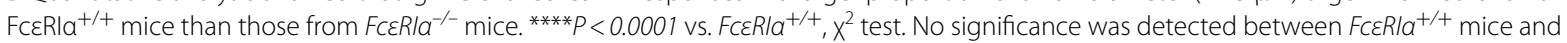

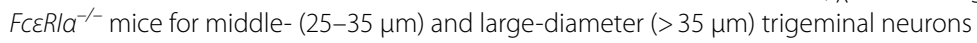

\section{FceRla mediated acute ocular itch induced by $\lg \mathrm{E}-\mathrm{IC}$}

Since FceRI $\alpha$ is the subunit combining IgE-IC, we applied global FceRI $\alpha$ knockout $\left(F c \varepsilon R I \alpha^{-/-}\right)$mice to determine whether FceRI $\alpha$ mediates the acute ocular itch induced by IgE-IC. The FcERI $\alpha^{-/-}$mice exhibited normal pain-like ocular reaction (wiping) to the algesic substance (capsaicin) compared with $F c \varepsilon R I \alpha^{+/+}$mice (Fig. 4A, B). In addition, pruritogens (histamine) could induce normal itch-like ocular reaction (scratching) in FcERI ${ }^{-/-}$mice compared with FceRI ${ }^{+/+}$mice (Fig. 4C, D). However, the ocular scratching responses to conjunctival instillation of IgE-IC were significantly attenuated in $F_{c \varepsilon R I \alpha^{-/-}}$mice compared with $F c \varepsilon R I \alpha^{+/+}$mice (Fig. 4E, F). These findings suggest that FceRI $\alpha$ is necessary for IgE-IC-elicited acute ocular itch. Given that FceRI $\alpha$ was also expressed in mast cells, we next investigated whether mast cells were required for IgE-IC-induced acute ocular itch. In the mast cell-deficient $c$-Kit ${ }^{W-s h / W-s h}$ mouse line, we observed no significant differences in basal or in IgE-ICevoked ocular scratching behavior compared with WT controls (Fig. 4G, H). Together, these results indicate that the acute itch effects of IgE-IC are mediated by FceRI $\alpha$, but do not specifically require mast cells, which suggests that IgE-IC might directly combine FceRI $\alpha$ in conjunctiva-innervating TG neurons to elicit itch sensation.

\section{Neuronal FceRla mediated acute ocular itch induced by IgE-IC}

To more specifically identify the role of neuronal FceRI $\alpha$ in the IgE-IC-induced ocular itch, we applied AAVmediated FceRI $\alpha$-knockdown under the control of Pirt promoter (AAV9-Pirt-shFceRI $\alpha$-EGFP), a strong and selective pan-DRG and TG promoter. Western blot analysis validated the effectiveness of shFceRI $\alpha$ sequenceloaded virus which interfered with trigeminal FceRI $\alpha$ expression compared with $\mathrm{NC}$ sequence-loaded virus (AAV9-Pirt-NC-EGFP) (Fig. 5A). In addition, we detected the EGFP signal 14 days after the intra-TG injection together with decreased expression of FceRI $\alpha$ trigeminal neurons in the AAV9-pirt-shFceRI $\alpha$-EGFP group. Nevertheless, expression of FceRI $\alpha$ in the spleen presented no difference for mice receiving the intr-TG injection of 

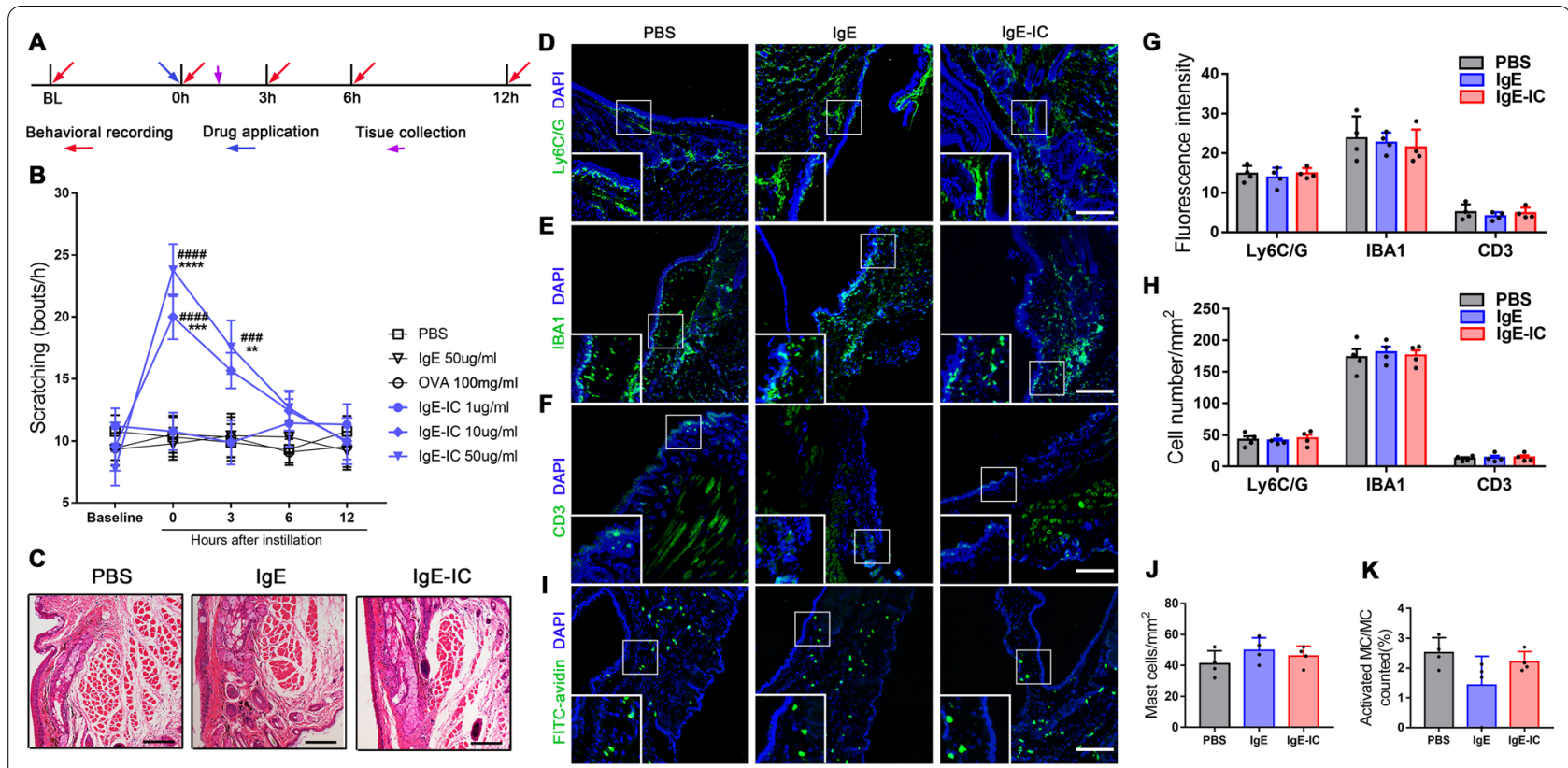

Fig. 3 IgE-IC elicits acute ocular itch in naive mice. A Timeline of behavioral recording, drug application, and tissue collection. B Mice were ocular instilled with $\operatorname{lgE}-\mathrm{IC}(1,10,50 \mu \mathrm{g} / \mathrm{ml} ; 5 \mu \mathrm{l})$, monomeric $\lg \mathrm{E}(50 \mu \mathrm{g} / \mathrm{ml} ; 5 \mu \mathrm{l})$, OVA (100 mg/ml, $5 \mu \mathrm{l})$ or vehicle (PBS; $5 \mu \mathrm{l})$, and eye-towards scratching bouts were counted over 1-12 h. Baseline was identified as recorded without any instillation. $n=8-10$ mice per group; ${ }^{* *} P<0.01$ vs.

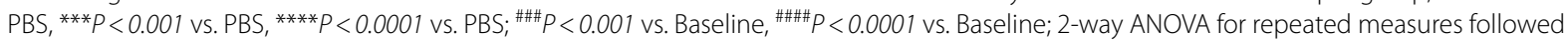
by Bonferroni's post hoc test. C Representative images of conjunctiva taken $1 \mathrm{~h}$ after ocular instillation with PBS, monomeric lgE $(50 \mu \mathrm{g} / \mathrm{ml})$, or IgE-IC $(50 \mu \mathrm{g} / \mathrm{ml})$, stained with H\&E. Scale bar: $100 \mu \mathrm{m}$. D-F Representative images of conjunctiva taken $1 \mathrm{~h}$ after ocular instillation with either PBS, monomeric $\lg E(50 \mu \mathrm{g} / \mathrm{ml})$, or $\operatorname{lgE}-\mathrm{IC}(50 \mu \mathrm{g} / \mathrm{ml})$ and stained for Ly6C/G (D), IBA1 (E), and CD3 (F). Scale bar: $100 \mu \mathrm{m}$. The embedded boxes showed the enlarged views. G Quantification for fluorescence intensity of markers showed no significant differences between treatment groups. $n=4$ per group; one-way ANOVA followed by Bonferroni's post hoc test comparisons. $\mathbf{H}$ Quantitative analysis of Ly6C/G+, IBA+, and CD3+ cell numbers after different treatments. $n=4$ per group; one-way ANOVA followed by Bonferroni's post hoc test comparisons. I Representative images of conjunctiva taken $1 \mathrm{~h}$ after ocular instillation with either PBS, monomeric lgE $(50 \mu \mathrm{g} / \mathrm{ml})$, or lgE-IC $(50 \mu \mathrm{g} / \mathrm{ml})$ and stained for FITC-avidin. Scale bar: $100 \mu \mathrm{m}$. The embedded boxes showed the enlarged views. J Quantitative analysis of mast cells number after different treatments. $n=4$ per group; one-way ANOVA followed by Bonferroni's post hoc test comparisons. K Proportions of activated mast cells (with degranulation) after different treatments. $n=4$ per group; one-way ANOVA followed by Bonferroni's post hoc test comparisons

these two types viruses (Fig. 5B). To check the normality of acute pain and itch reaction, we applied ocular instillation of capsaicin and histamine to mice infected by these two viruses. Both the wiping reaction to capsaicin and the scratching reaction to histamine showed no difference between these two groups, indicating that neuronal FceRI $\alpha$-knockdown did not alter the baseline nociception (Fig. 5C-F). As instilled IgE-IC $(50 \mu \mathrm{g} / \mathrm{ml})$ into the inferior conjunctival sac, mice infected by the control virus presented scratching behavior directed at the treated conjunctiva, which could last to $3 \mathrm{~h}$ after instillation. Infected by the shFceRI $\alpha$-loaded virus, mice exhibited immediate scratching reaction as stimulated by IgE-IC, whereas the degree was significantly decreased compared with the control virus group. Moreover, no obvious itch reaction was detected for mice infected by shFceRI $\alpha$ loaded virus $3 \mathrm{~h}$ after IgE-IC application compared with PBS (Fig. 5G). In addition, the pain-related wiping reaction could not be evoked by IgE-IC for mice infected by both two types of viruses (Fig. 5H). The H\&E staining for the conjunctivas did not detect any signs of conjunctival inflammation at $1 \mathrm{~h}$ after instillation (Fig. 5I). The above findings suggest that IgE-IC evokes acute ocular itch, at least partly, through neuronal FceRI $\alpha$.

\section{ACJ upregulated the expression of FceRla in TG innervating the conjunctiva}

To observe the neuronal expression of FceRI $\alpha$ under allergic conditions, we produced an OVA-mediated allergic conjunctivitis (ACJ) murine model (Fig. 6A). Western blot results showed that the protein level of trigeminal FceRI $\alpha$ was significantly upregulated in ACJ mice compared with the vehicle control-treated animals (Fig. 6B). To specifically compare the expression of FceRI $\alpha$ in conjunctival sensory neurons, we injected WGA into conjunctiva for control and ACJ mice and detected FceRI $\alpha$ within WGA-labeled trigeminal neuron. The immunofluorescence results showed that 


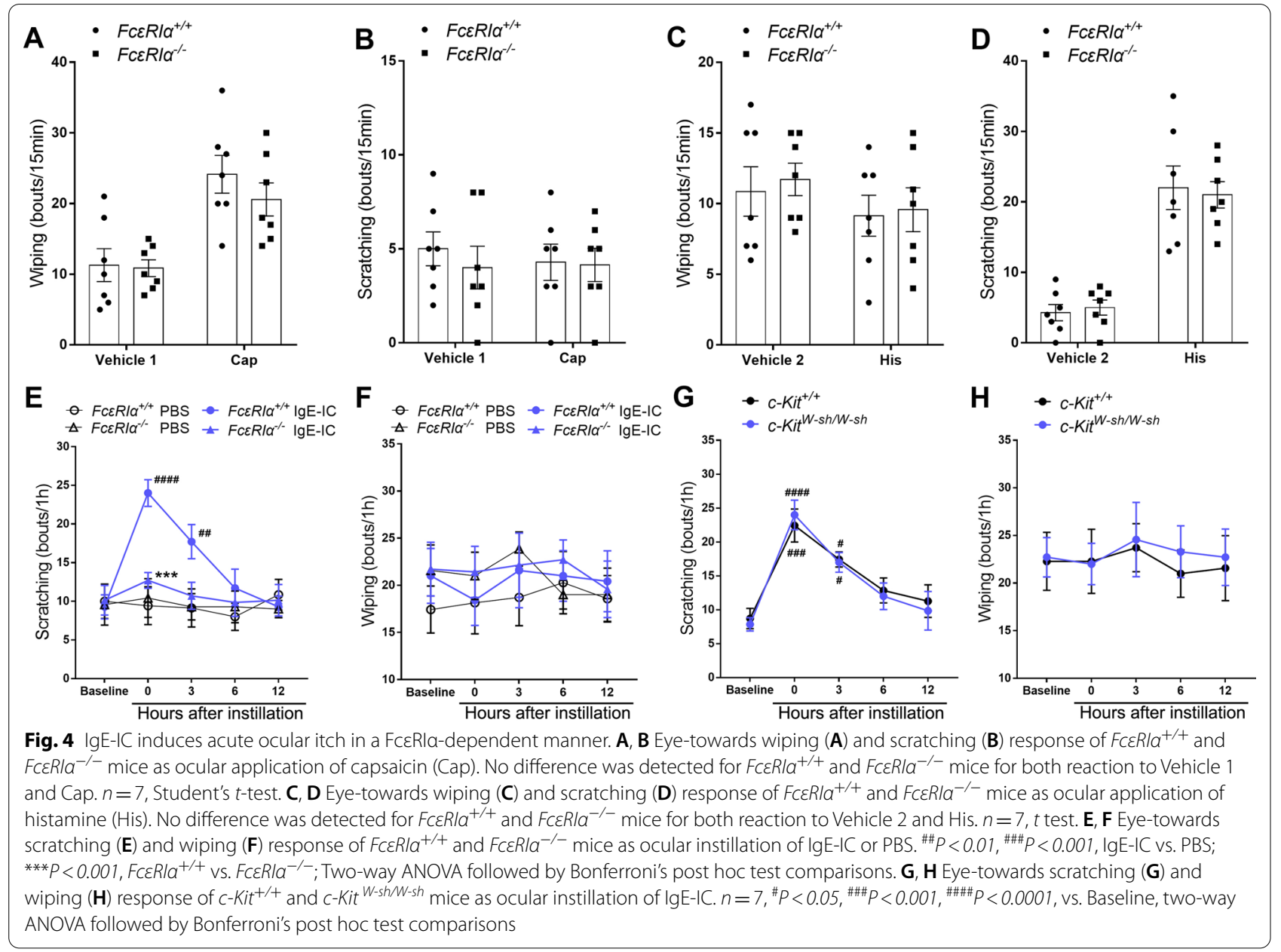

the percentage of WGA-labeled FceRI $\alpha^{+}$neurons was significantly increased in ACJ mice (Fig. 6C, D). To further identify the character of these conjunctival FceRI $\alpha^{+}$sensory neurons, we applied double immunostaining for FceRI $\alpha$ and a series of markers. Among these FceRI $\alpha^{+}$conjunctiva sensory neurons, no significant difference was detected in NF200 and IB4 markers in ACJ mice as compared with the control-treated mice (Fig. 6E-H). However, an elevated proportion of FceRI $\alpha^{+}$conjunctiva sensory neurons in ACJ mice coexpressed CGRP (Fig. 6I, J). Meanwhile, the percentage of FceRIa ${ }^{+}$sensory neurons was also increased among $\mathrm{MrgprA3}^{+}$pruriceptors (from 13.38 to $28.07 \%$ ). In addition, no obvious $\mathrm{GS}^{+}$signal was detected within FceRIa ${ }^{+}$neurons innervating conjunctiva for both $\mathrm{ACJ}$ and control-treated mice (Fig. 6K, L). Moreover, we did not detect obvious immune cell infiltration within TG for ACJ mice compared with the control-treated mice (Additional file 1: Fig. S4). These findings suggest that the expression of FceRI $\alpha$ in conjunctival sensory neurons is significantly upregulated under ACJ condition.
Neuronal FceRla mediated allergic ocular itch in ACJ model Given that FceRI $\alpha$ was upregulated in $\mathrm{CGRP}^{+}$nociceptors and $\mathrm{MrgprA3}^{+}$pruriceptors in ACJ, and IgE-IC could evoke acute ocular itch through neuronal FceRI $\alpha$, we next asked whether neuronal FceRI $\alpha$ was involved in ocular itch under allergic conjunctivitis condition. From 14th day after intra-TG virus injection (AAV9pirt-shFceRI $\alpha$-EGFP and AAV9-pirt-NC-EGFP), we produced ACJ model. Following challenged by OVA, the ACJ pathology was induced in ACJ group (sensitized on day 0 , and boosted on day 7 and day 14) mice, but not control-treated mice (challenged by OVA without any sensitization). However, no obvious difference was detected in $\mathrm{H} \& \mathrm{E}$ staining between the mice infected by AAV9-pirt-NC-EGFP and the ones infected by AAV9pirt-shFceRI $\alpha$-EGFP, indicating that neuro-knockdown of FceRI $\alpha$ did not affect the development of ACJ pathology (Fig. 7A). The Western blot results showed that trigeminal FceRI $\alpha$ was significantly upregulated in ACJ model for mice infected by NC-loaded virus, whereas no alteration was detected for the shFceRI $\alpha$-loaded virus group. In 


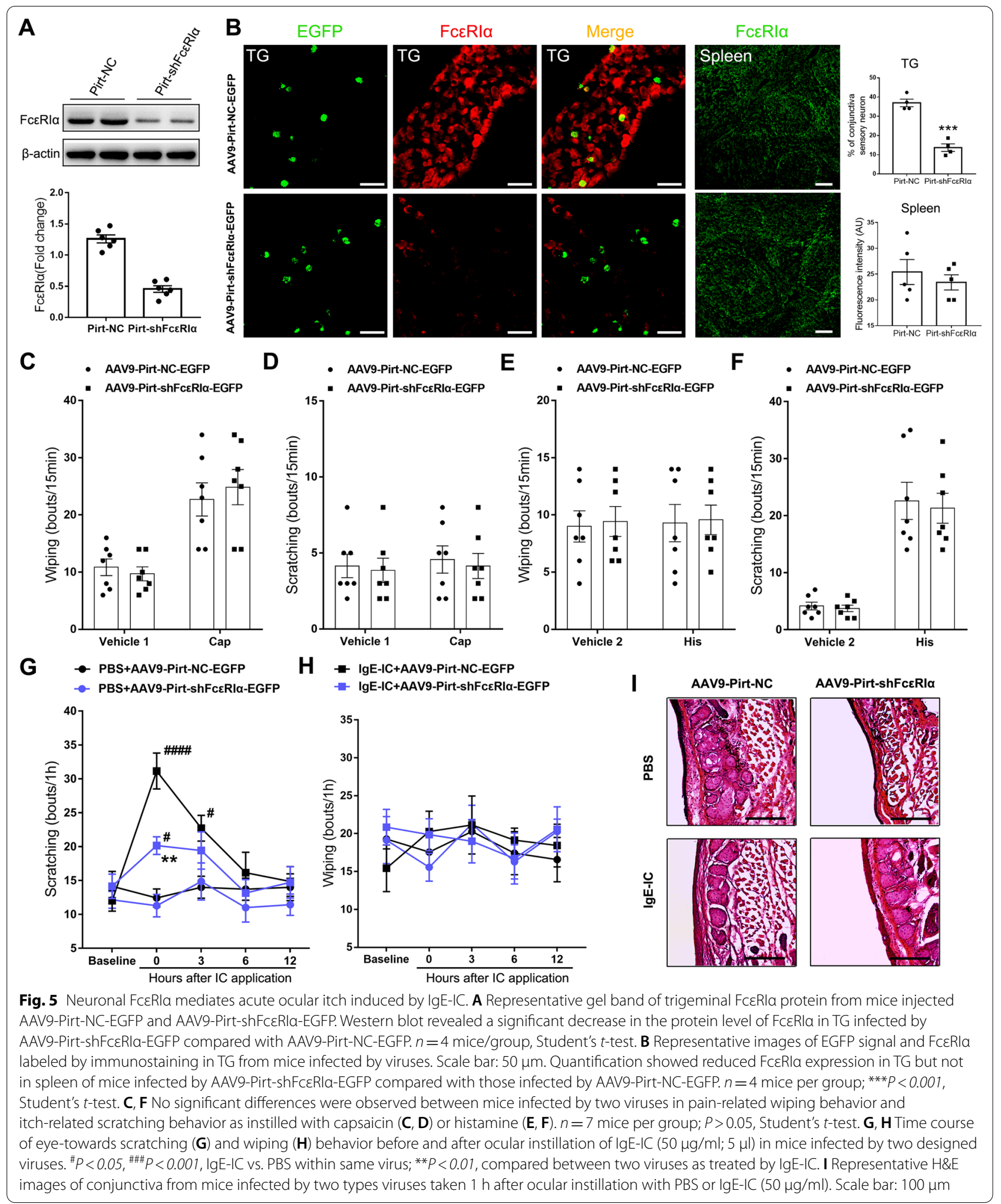


addition, the trigeminal expression of FceRI $\alpha$ was significantly downregulated in the AAV9-pirt-shFceRIa-EGFP group compared with the AAV9-pirt-NC-EGFP group, both control- and ACJ-treated mice (Fig. 7B, C). As challenged by OVA, mice infected by the shFceRI $\alpha$-loaded virus showed significantly reduced ocular itch than those infected by the NC-loaded control virus (Fig. 7D). To determine the role of conjunctival inflammation in the reduced itch as neuro-knockdown of FceRI $\alpha$, IF was applied to assess the immune cell infiltration. Quantification showed a significant increase in Ly6C/G, IBA1, and $\mathrm{CD} 3$ in the conjunctiva following $\mathrm{ACJ}$ for mice infected by both two viruses. Notably, neuro-knockdown of FceRI $\alpha$ in the AAV9-pirt-shFceRI $\alpha$-EGFP group showed no influence on the infiltration of neutrophils (Ly6C/G), macrophages (IBA1), and lymphocytes (CD3) following ACJ, compared with the AAV9-pirt-NC-EGFP group (Additional file 1: Fig. S5). In addition, we next examine the effects of neuron-specific knockdown FceRI $\alpha$ on infiltration and activation of mast cells under ACJ conditions. The numbers of mast cells showed no difference in the AAV9-pirt-shFceRI $\alpha$-EGFP group compared with the AAV9-pirt-NC-EGFP group, for both control- and ACJtreated mice. Moreover, the percentages of degranulated mast cells also showed no difference for the mice infected by AAV9-pirt-shFceRI $\alpha$-EGFP. Above all, these results suggested that neuronal FceRI $\alpha$ directly mediated allergic ocular itch in ACJ model (Fig. 7E-G).

\section{IgE upregulated the neural expression of FceRla with elevated neural excitability in TG}

To explore the regulatory mechanism of neuronal FceRI $\alpha$, the mRNA and protein level of FceRI $\alpha$ in dissociated TG neurons cultured by media containing different concentrations of isotype IgE were determined by qRT-PCR and Western blot. The FceRI $\alpha$ protein increased significantly in dissociated TG neurons cultured with IgE without significant changes in the level of mRNA (Fig. 8A, B). Cycloheximide $(10 \mu \mathrm{g} / \mathrm{ml})$, a potent inhibitor of translation, failed to block the effect of $\operatorname{IgE}(5 \mu \mathrm{g} / \mathrm{ml})$ in the upregulation of FceRIa (Fig. 8C). To further examine the effects of IgE on the excitability of TG neurons, we conducted calcium imaging of the dissociated TG neurons (Fig. 8D). Calcium imaging showed that small-size neurons cultured with isotype IgE $(5 \mu \mathrm{g} / \mathrm{ml})$ responded to IgE-IC intensively. No difference was observed for middle-size and large-size neurons. The percentage of IgE-IC-responsive neurons and the magnitude of IgE-ICevoked $\mathrm{Ca}^{2+}$ responses were significantly increased when IgE was added into the culture media (Fig. 8E, F). Calcium imaging was also conducted for dissociated neurons from Mrgpra $3^{G F P-C r e}$ mice, which detected the responses of $\mathrm{MrgprA3}^{+}$neurons to IgE-IC. For MrgprA3 ${ }^{+}$neurons, $\operatorname{IgE}(5 \mu \mathrm{g} / \mathrm{ml})$ increased the percentage of IgE-IC-responsive neurons (from 25.22 to $39.02 \%)$ and the intensity $(\Delta R$ (340/380) from 22 to $30 \%$ baseline) of the $\mathrm{Ca}^{2+}$ responses (Additional file 1: Fig. S6). To in vivo observe the role of IgE for neuro-expression of FceRI $\alpha$, we designed an incremental sensitization workflow (Additional file 1: Fig. S7A). First, we detected elevated OVA-specific IgE in the serum of sensitized mice, suggesting that boost could sustain the level of IgE in the serum and extended sensitization increased the action time of IgE to sensory neurons (Additional file 1: Fig. S7B). We further found that levels of FceRI $\alpha$ in TG neurons were significantly increased in mice sensitized 2 weeks $(2 \mathrm{w})$ and sensitized 3 weeks $(3 \mathrm{w})$ compared with mice of control-treated and sensitized 1 week ( $1 \mathrm{w})$ (Fig. 8G). Immunofluorescent staining showed that the increased FceRI $\alpha$ was mainly detected in small-sized TG neurons in the groups of sensitized $2 \mathrm{w}$ and sensitized $3 \mathrm{w}$ compared with controltreated group and sensitized $1 \mathrm{w}$ group (Additional file 1: Fig. S7C, D). To determine the effect of sensitized duration on the ocular pruritus degree, we dropped allergen (1\% OVA in PBS) to the eyes of mice with increased times of sensitization. We found that sensitized mice presented scratching behavior as challenged by allergen, but not the unsensitized mice. Notably, incremental sensitization induced aggravating scratching behavior when treated with OVA (Fig. $8 \mathrm{H}$ ). The above results indicate that IgE might upregulate neuronal FceRI $\alpha$ and further intensify pruritus degree as antigen exposure.

\section{Discussion}

From the conventional theory, FceRI, a high-affinity activating receptor for IgE, is mainly expressed in allergyrelated cells, such as mast cells and basophils. The cross-linking of FceRI induced by the combination of

\footnotetext{
(See figure on next page.)

Fig. 6 ACJ upregulates the expression of FceRla in mouse TG neurons innervating conjunctiva. A Schematic diagram of ACJ model construction and workflow. B Representative gel band of FceRla protein in TG from control and ACJ mice. Western blot revealed a significant increase in the level of FcERla protein in TG. $n=4$ mice/group, ${ }^{* * *} P<0.001$, ACJ vs. Control mice, Student's $t$-test. C Typical microscopic images of immunofluorescence staining for FcERla in TG sections retrogradely labeled by conjunctival wheat germ agglutinin (WGA) from Control and ACJ mice. D ACJ upregulated FceRla+ among WGA-labeled conjunctiva sensory neuron. Each point represents data from one mouse, $n=5$ mice/group, ${ }^{*} P<0.05$, Student's $t$-test. Scale bar: 50 Mm. E-L. Representative images of TG immunofluorescence staining for FceRla and NF200 (E), IB4 (G), CGRP (I) and GS (K) in sections containing sensory neurons retrogradely labeled by conjunctival WGA from Control and ACJ mice. Percentage of NF200 ${ }^{+}(\mathbf{F}), \mathrm{IB}^{+}(\mathbf{H}), \mathrm{CGRP}^{+}(\mathbf{J})$, and $\mathrm{GS}^{+}(\mathbf{L})$ markers among FceRla ${ }^{+}$conjunctiva sensory neurons in Control and ACJ mice was summarized. Each point in $\mathbf{F}, \mathbf{H}, \mathbf{J}$, and $\mathbf{L}$ represented data from one mouse, $n=4$ mice/group, ${ }^{*} P<0.05$, Student's $t$-test. Scale bar: $50 \mu \mathrm{m}$
} 


\begin{tabular}{|c|c|c|c|c|}
\hline \multirow{2}{*}{$\mathbf{A}$} & \multicolumn{3}{|c|}{ Control } & \multirow[b]{2}{*}{$\longleftarrow$ OVA instillation } \\
\hline & 1 & 1 & $\pm \backslash$ & \\
\hline Day 0 & Day 7 & Day 14 & Day 21 & $\leftarrow$ OVA sensitization \\
\hline 1 & 1 & 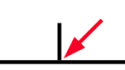 & $\pm \searrow$ & $\leftarrow$ WGA injection \\
\hline Day 0 & Day 7 & Day 14 & Day 21 & $\longleftarrow$ Tissue collection \\
\hline
\end{tabular}

B

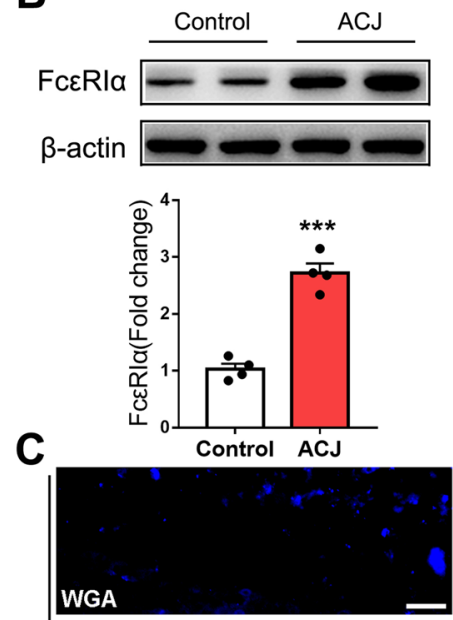

E $\quad$ WGA Fcerla NF200
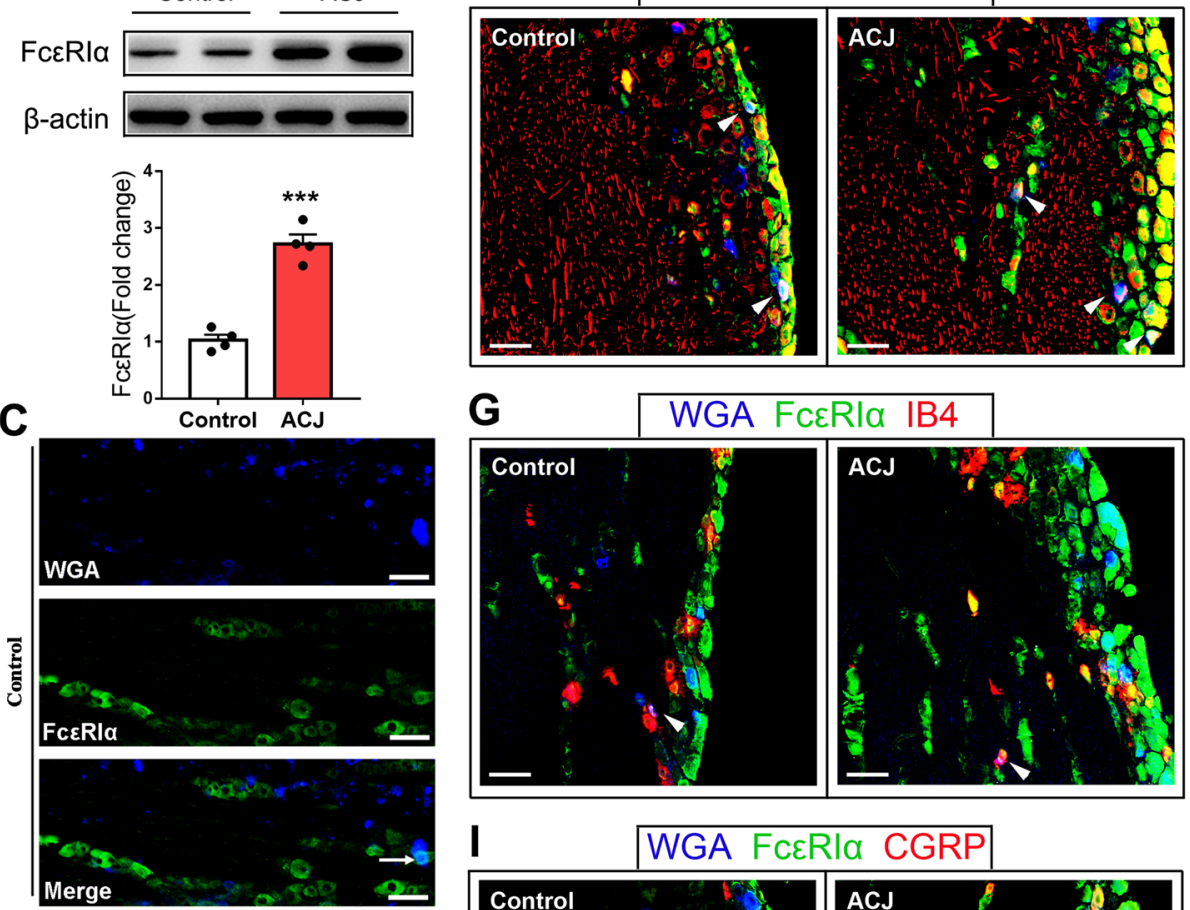

$F$
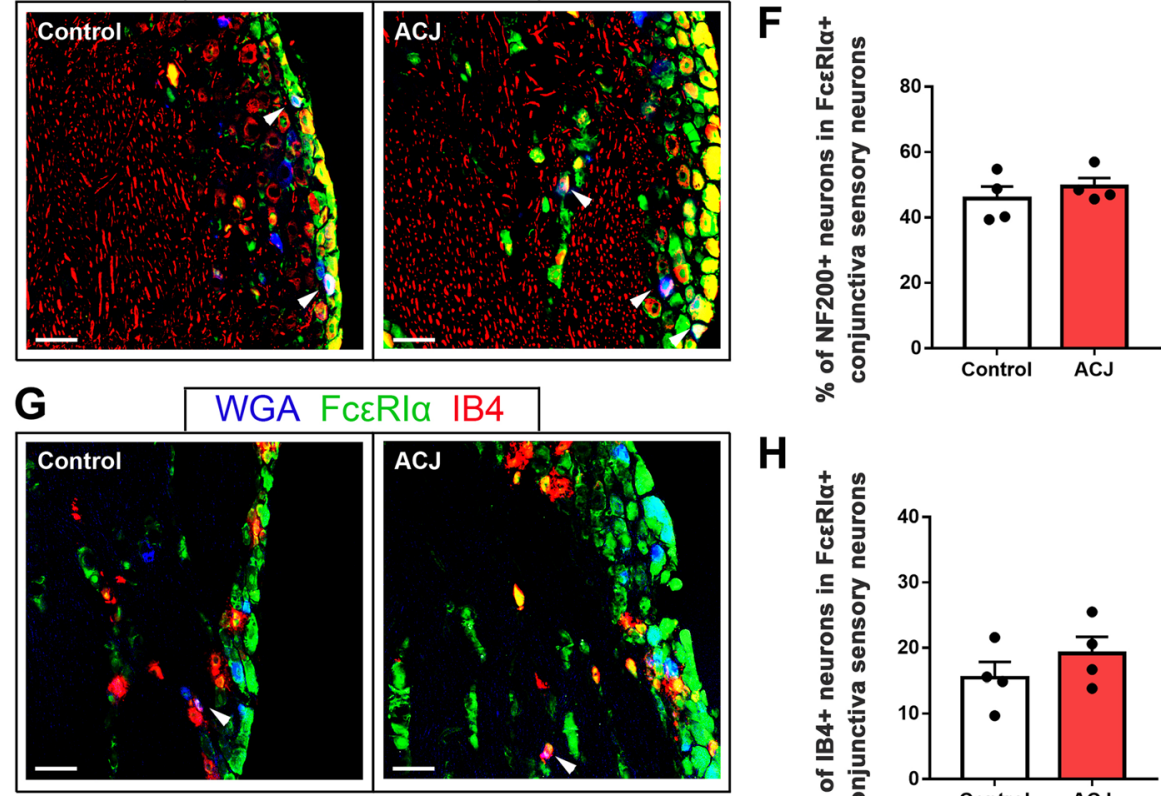

$\mathrm{H}$
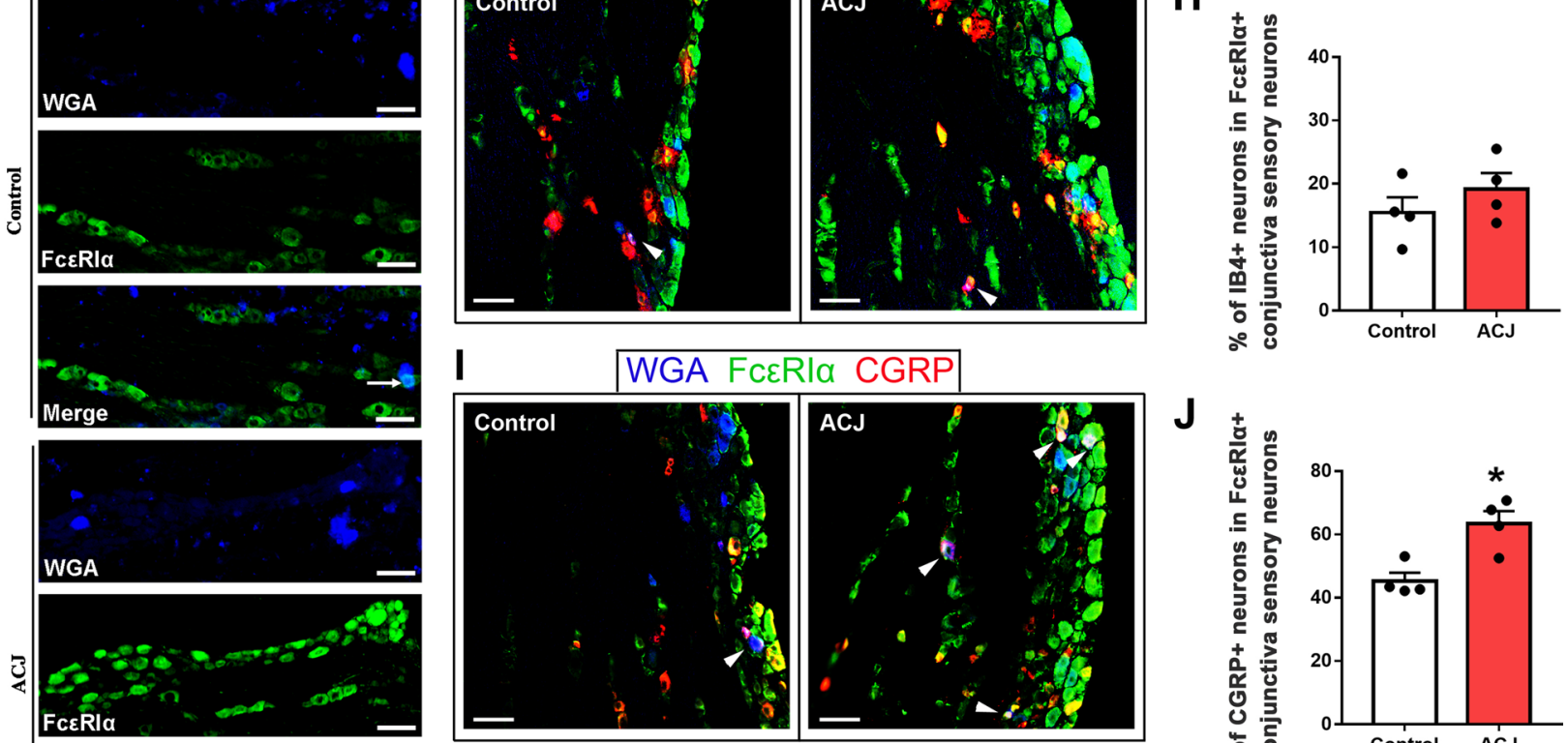

$J$
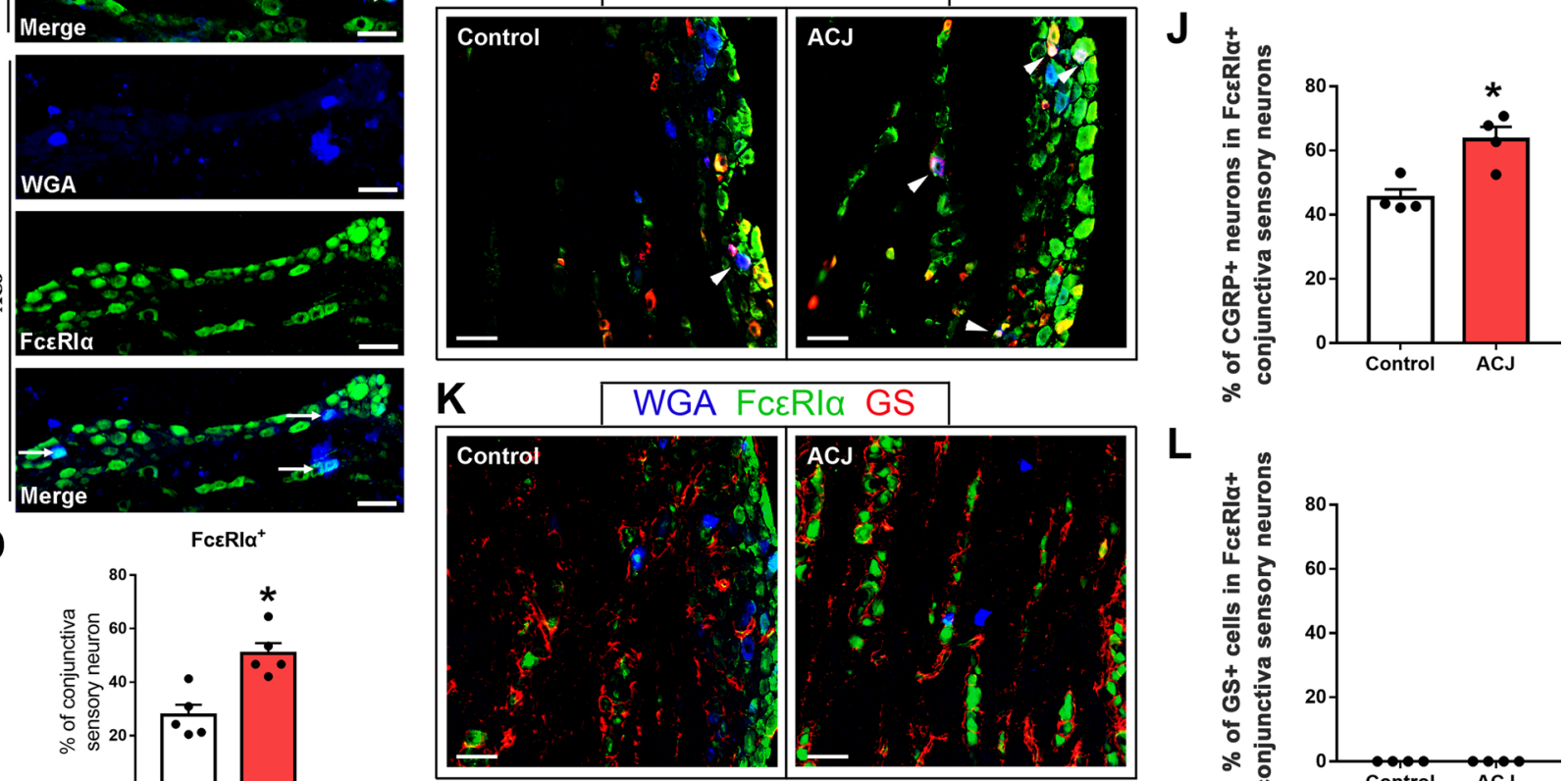

$\mathbf{L}$

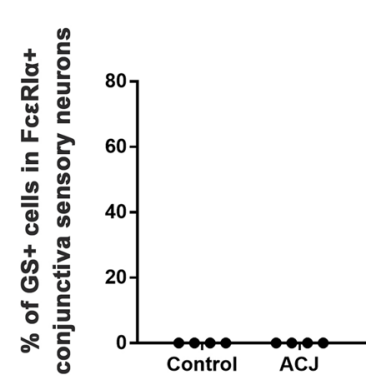

Fig. 6 (See legend on previous page.) 
IgE-IC with $\alpha$ subunit of FceRI (FceRI $\alpha$ ) triggers degranulation of mast cells and release of inflammatory mediators, such as histamine, tryptase, platelet-activating factor, and prostaglandin E2 [34, 35]. Notably, we and others have previously reported that sensory neurons expressed FceRI including all three subunits FceRI $\alpha$, FceRI $\beta$, and FceRI $\gamma$. The present study focused on the IgE-binding subunit FceRI $\alpha$ and further identified that FceRI $\alpha$ was functionally and anatomically expressed in a subset of conjunctiva-innervating sensory neurons. We detected FcERI $\alpha$ protein expression in conjunctival sensory neurons of $\mathrm{NF}^{2} 20^{+}$myelinated sensors and nociceptors, including both $\mathrm{CGRP}^{+}$peptidergic and $\mathrm{IB}^{+}$ nonpeptidergic neurons. Using calcium imaging, we also demonstrated that IgE-IC could directly activate trigeminal neurons in a manner dependent on FceRI $\alpha$. The distribution of other two subunits of FceRI, FceRI $\beta$, and FceRI $\gamma$, among conjunctiva-innervating sensor and their role in neuronal activation could be further identified to acquire a complete understanding of sensory FceRI.

Another advance in this study is the revelation of a novel role for neuronal FceRI $\alpha$ in ocular itch perception. MrgprA3, the pruriceptor of chloroquine, marked a subpopulation of conjunctiva-specific neurons that transmit acute and allergic-related ocular itch [29]. We detected FceRI $\alpha$ expression in both the soma and the fiber of $\mathrm{MrgprA3}^{+}$neurons, which could be directly activated by IgE-IC. Based on these discoveries, we investigated the effect of IgE-IC on the ocular sensation and the role of neuronal FceRIa in it. First, conjunctival instillation of IgE-IC evoked eye-towards scratching behavior without obvious pain-related wiping, indicating that IgE-IC served as itch-specific regent for conjunctiva. Strikingly, this scratching behavior seemed to be dissociable from conjunctival inflammation, at least at an early stage, and the function of mast cells. Moreover, both global deletion and specifically Pirt-guided neuronal knockdown in trigeminal sensory neurons effectively alleviated the acute ocular itch induced by IgE-IC, suggesting that neuronal FceRI $\alpha$ could independently mediate the acute ocular itch induced by IgE-IC.
Itch and pain are the main symptoms of various allergic conditions, which are considered as the consequence of intensive immune activation within the affected tissue $[33,36,37]$. However, current therapeutic strategies for these allergic-related nociception managements rely heavily on immune-suppressive drugs and often have limited efficacy or induced consequential complications. Recent studies demonstrated that Fc $\gamma$ RI on joint-innervating sensor exhibited hypersensitivity and FcyRIcoupled signaling in peripheral nociceptor could mediate joint pain independently in allergic arthritis through conditional neuronal knockout animal model [38-40]. These studies indicated that peripheral sensitization of nociceptors mediated by the neuronal adaptive immune receptors as challenged by the immune complex might be a brand-new mechanism for allergic-related nociception.

Based on the clinical evidence that IgE was increased in the serum of allergic conjunctivitis patients and the above laboratory observation, the role of neuronal FceRI in ocular itch under allergic conjunctivitis was further explored through ACJ murine model. The conjunctiva-innervating sensors increasingly expressed FceRI $\alpha$ which co-expressed CGRP at a greater proportion in ACJ model. Previous studies reported that $\mathrm{CGRP}^{+}$sensory neurons encoded itch and presented anatomical specificity in the eye, more detected in the conjunctivainnervating neurons than in the cornea-innervating neurons $[29,41]$. Moreover, a higher percentage of trigeminal MrgprA3 $^{+}$pruriceptors expressed FceRI $\alpha$ in ACJ model, suggesting the upregulation of FceRI $\alpha$ in pruriceptors under ACJ condition. Our previous study showed that pharmacological antagonism to FceRI $\alpha$ could alleviate ocular itch in ACJ murine model, while this outcome might result from disturbance to neuronal FceRI $\alpha$ and/or FceRI $\alpha$ in mast cells [25]. In the present study, we applied neuronal-selective knockdown of FceRI $\alpha$ which significantly alleviated ocular itch as challenged by antigens, while the immune cell infiltration and mast cell activation were not altered. These findings provide promising and unique neuronal targets for new anti-ocular itch therapeutic strategies in ACJ.

\footnotetext{
(See figure on next page.)

Fig. 7 Neuronal FceRla mediates ocular itch in the ACJ murine model. A Representative H\&E images of conjunctiva from mice infected by two types of viruses taken $12 \mathrm{~h}$ after ACJ induction. Scale bar: $100 \mu \mathrm{m}$. B Representative gel band of FcERla protein in TG from control or ACJ-treated mice after trigeminal injection of two types viruses. CWestern blot revealed a significant decrease in the level of FceRla protein in Pirt-shFceRla group compared with Pirt-NC group for both control and ACJ-treated mice. $n=4$ per group, ${ }^{* *} P<0.01,{ }^{* * *} P<0.001$, Pirt-shFCERla vs. Pirt-NC, Student's t-test. D Eye-towards scratching behavior in ACJ model as challenged by OVA was significantly decreased in Pirt-shFcERla group compared with Pirt-NC group, while no difference was discovered in control-treated mice between two types viruses. $n=7$ per group, ${ }^{*} P<0.05$, Pirt-shFcERla vs. Pirt-NC, Student's t-test. E Representative images of conjunctiva from mice infected by two types viruses taken $12 \mathrm{~h}$ after ACJ induction and stained for FITC-avidin. The mast cells in allergic conjunctiva presented as irregular shape with degranulation. The embedded boxes showed the enlarged views. Scale bar: $100 \mu \mathrm{m}$. F Quantitative analysis of mast cells number after different treatments. $n=6$ per group; ${ }^{* * *} P<0.001$, ${ }^{* * * *} P<0.0001$, ACJ vs. Ctrl infected by the same virus, Student's $t$-test. n.s. no significance, Pirt-shFceRla vs. Pirt-NC, Student's $t$-test. G Proportions of activated mast cells (with degranulation) after different treatments. $n=6$ per group; ${ }^{* *} P<0.001{ }^{* * * *} P<0.0001, A C J$ vs. Ctrl infected by the same virus, Student's $t$-test. n.s. no significance, Pirt-shFceRla vs. Pirt-NC, Student's $t$-test. Ctrl control, ACJ allergic conjunctivitis
} 


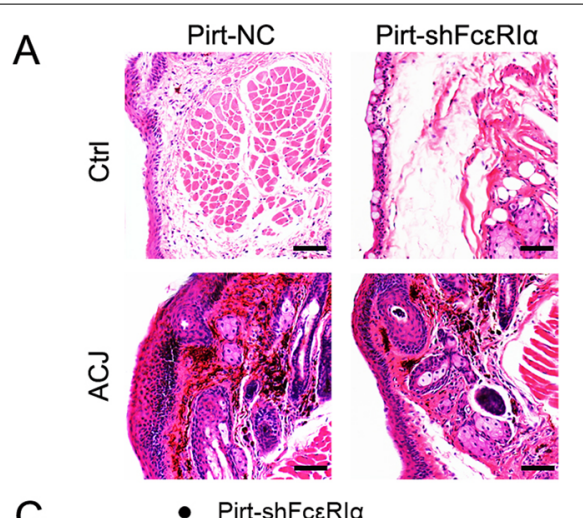

C
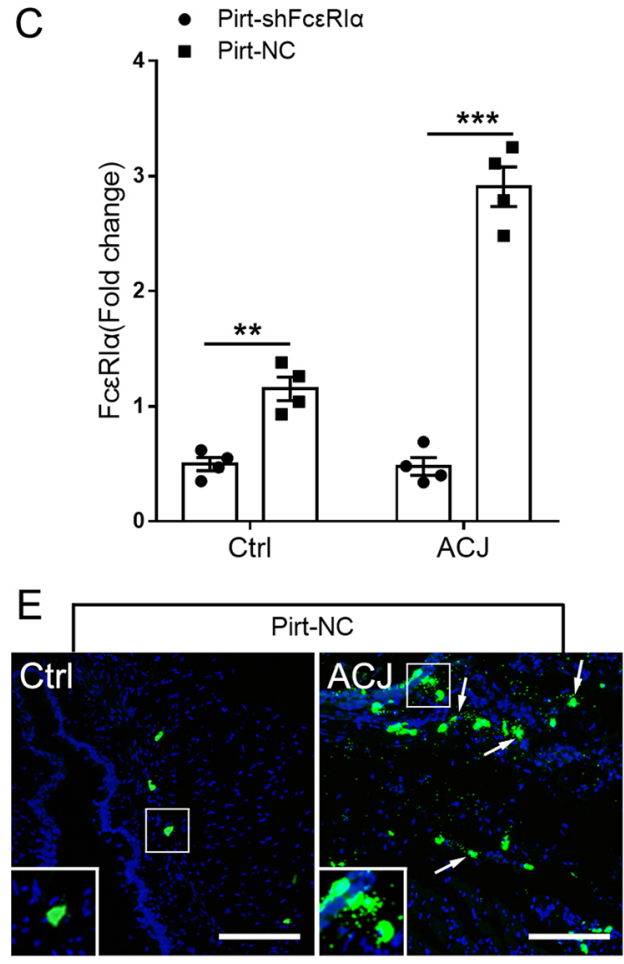

F
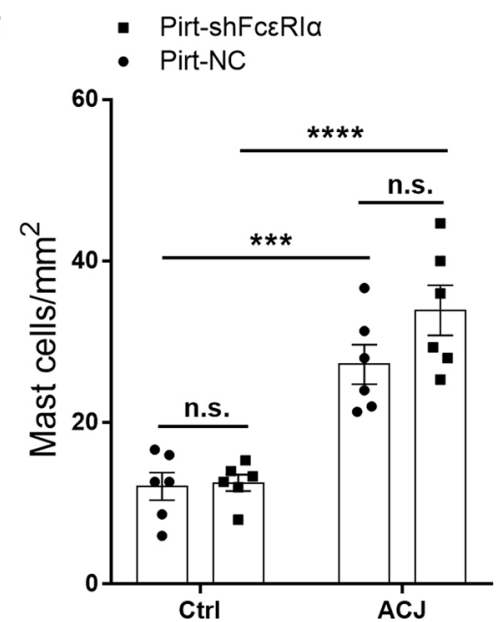

B

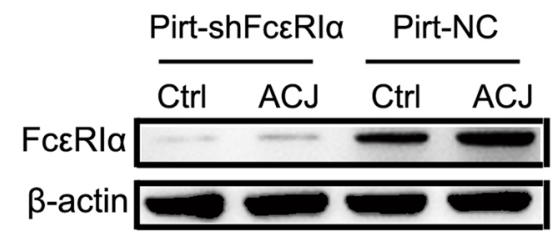

D
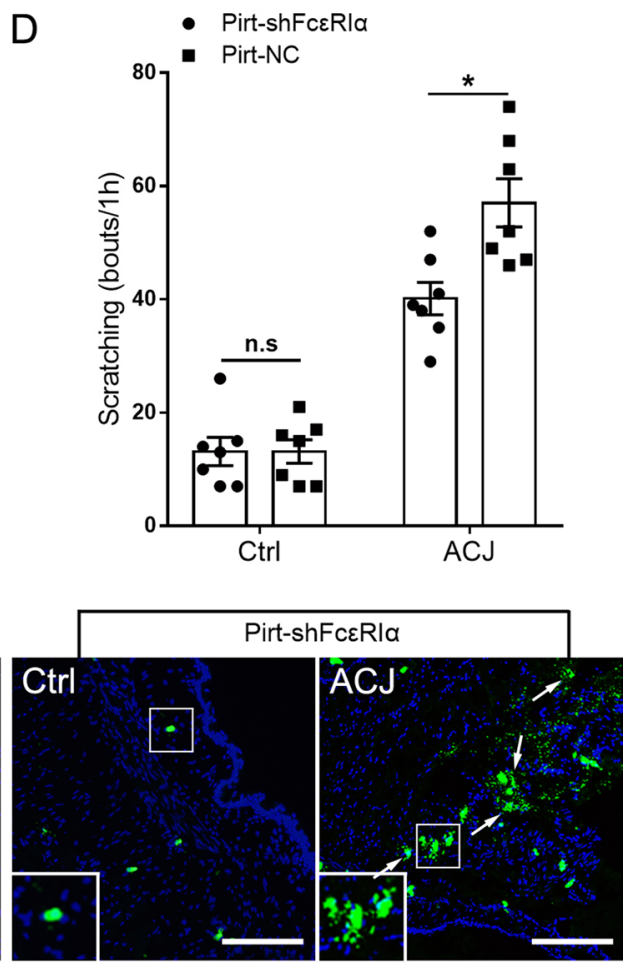

G

- Pirt-shFceRla

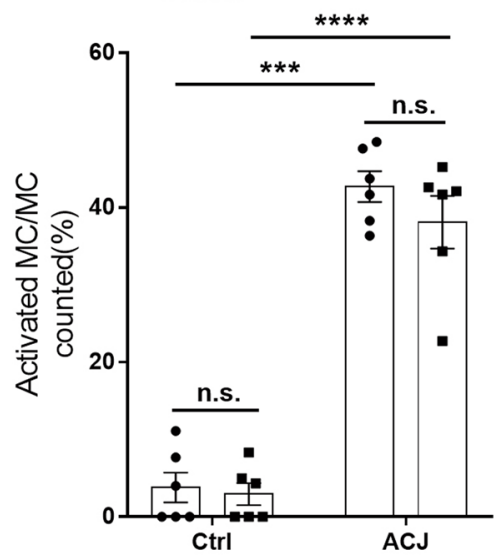

Fig. 7 (See legend on previous page.) 

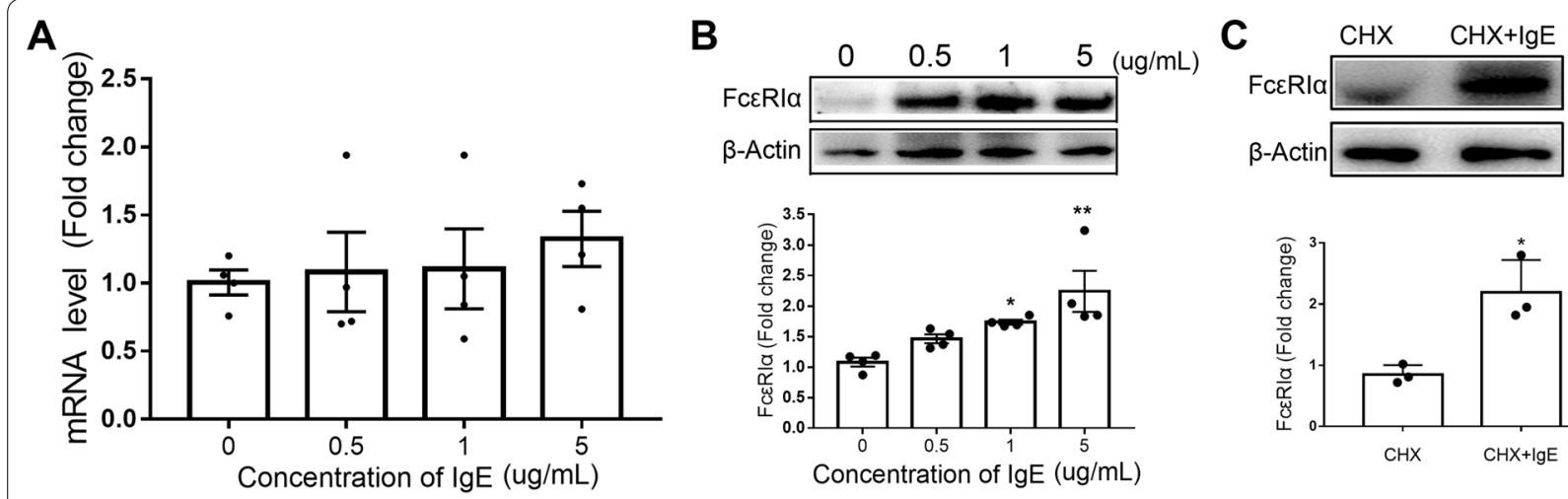

D

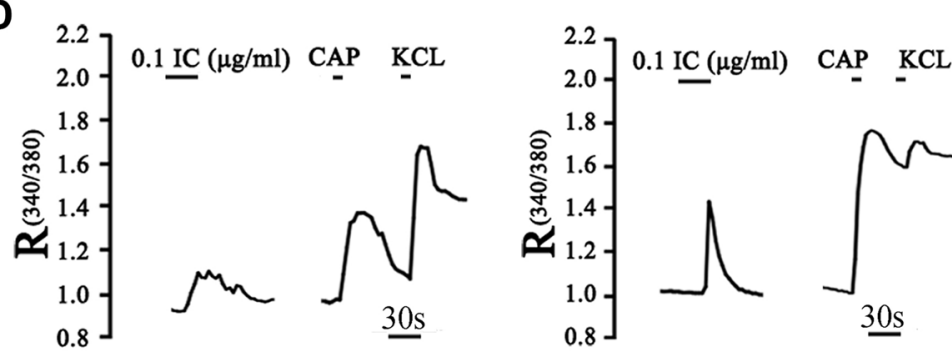

E
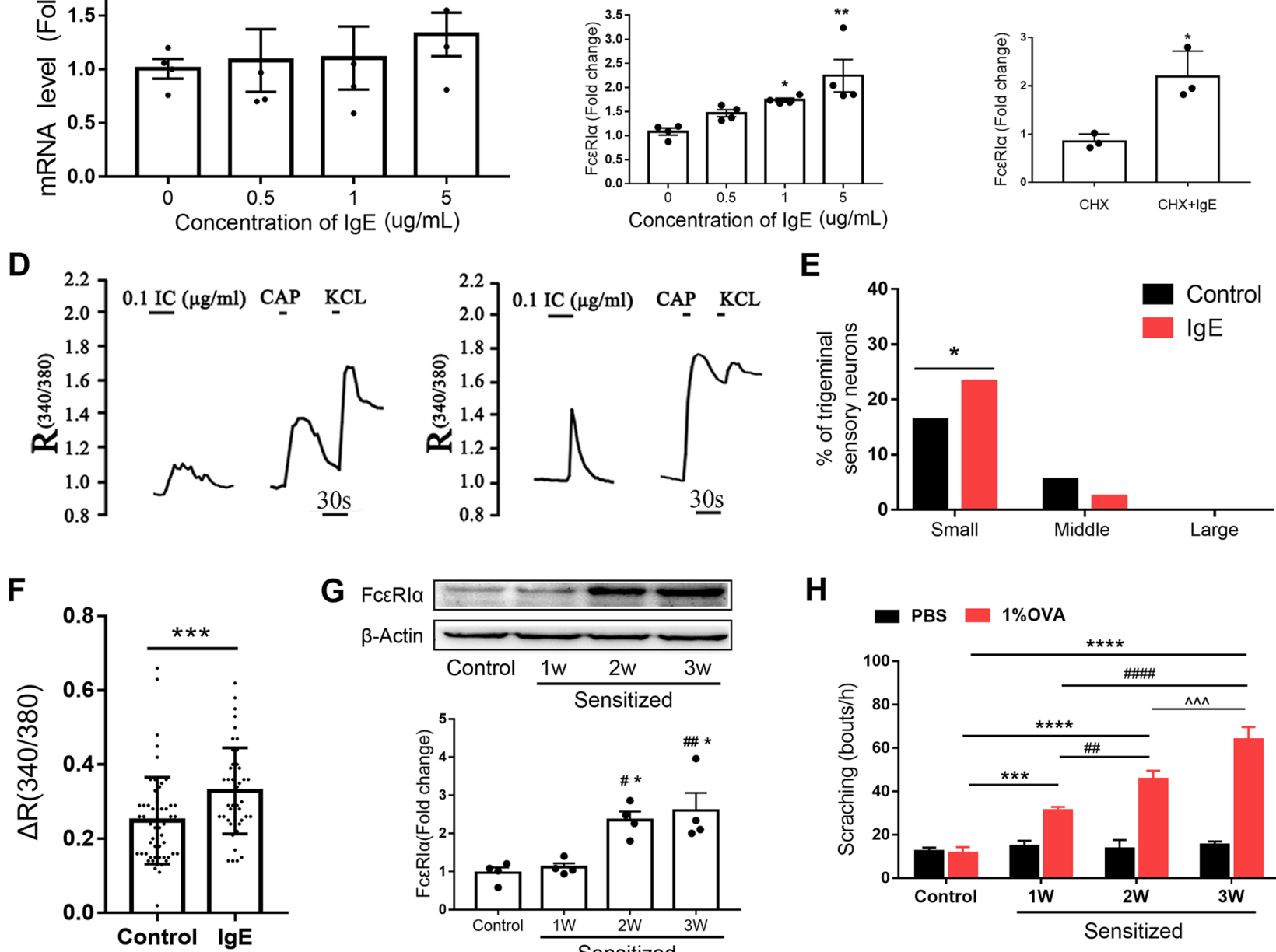

H

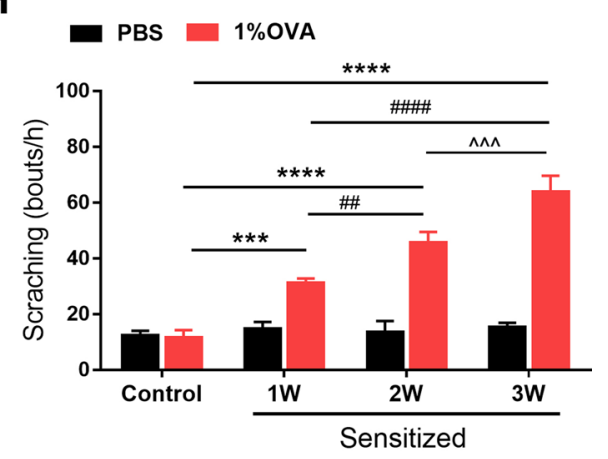

Fig. 8 lgE upregulates neuronal FcERla and enhanced neuronal response to lgE-IC. A qRT-PCR revealed that FceRla mRNA was not changed by lgE. One-way ANOVA followed by Bonferroni's post hoc test comparisons, $n=4$. B Representative Western blotting gel bands of FceRla protein from dissociated TG neurons cultured with IgE of different concentrations. Western blotting revealed a significant increase in the protein levels of FckRla in dissociated TG neurons cultured with IgE. ${ }^{*} P<0.05,{ }^{* *} P<0.01$, vs. Control, one-way ANOVA followed by Bonferroni's post hoc test comparisons, $n=4$. $C$ IgE upregulated the FceRla protein in dissociated TG neurons as blocking protein synthesis by Cycloheximide (CHX). ${ }^{*} P<0.05, \mathrm{CHX}$ vs. $\mathrm{CHX}+\mathrm{lgE}$, Student's $t$-test, $n=3$. D TG neurons cultured with (right, lgE group) and without (left, Control group) $\operatorname{lgE}(5 \mu \mathrm{g} / \mathrm{ml})$ were exposed to $\operatorname{lgE}-\mathrm{IC}(\mathrm{IC} ; 0.1 \mu \mathrm{g} / \mathrm{ml} ; 30 \mathrm{~s})$, followed by capsaicin (CAP; $1 \mu \mathrm{M} ; 10 \mathrm{~s})$ and $\mathrm{KCl}(50 \mathrm{mM} ; 10 \mathrm{~s})$. Neuronal activation was analyzed by calcium imaging (representative trace). E Proportion of responsive small-diameter neurons as IgE-IC application was significantly increased in IgE group compared with Control group. ${ }^{*} P<0.05$, IgE vs. Control, $X^{2}$ test. $\mathbf{F}$ Mean magnitude of IgE-IC-induced $R(340 / 380)$ growth was also elevated in IgE group. ${ }^{* * *} P<0.001$, IgE vs. Control, Student's t-test. G Protein levels of FcERla in TG from mice sensitized different times were determined by Western blotting. ${ }^{P}<<0.05,{ }^{\#} P<0.01$ vs. Control; ${ }^{*} P<0.05$ vs. Sensitized $1 \mathrm{~W}$, one-way ANOVA followed by Bonferroni's post hoc test comparisons. $\mathbf{H}$ Ocular scratching behavior as challenged by OVA (1\% in PBS) or vehicle in mice sensitized different times. $n=6$ per group, ${ }^{* * *} P<0.001,{ }^{* * * *} P<0.0001$ vs. Control; ${ }^{\#} P<0.01, \# \# \#<0.0001$ vs. Sensitized $1 w ; \wedge \wedge \wedge P<0.001$ vs. Sensitized $2 w$; Student's $t$-test

More recently, transient receptor potential canonical (TRPC) $3 / 6 / 7$ were identified as the key downstream effective channels in FceRI signaling in mast cells [42]. A previous study also demonstrated that neuronal Fc $\gamma$ RI was functionally coupled to TRPC3 to regulate the excitability of DRG neurons [43]. In addition, histamine receptor 1 (H1R) coupled TRPV1 to mediate histamine-dependent ocular itch, while platelet activating factor receptor (PAFR) engaged TRPA1 to consist the histamine-independent ocular itch pathway [30]. 
The intracellular signaling and effective ion channel of FceRI in sensory neurons should be further explored. To develop new therapy for itch symptom of ACJ patients, it is important to translate our discoveries from mice to humans [29]. Although the FceRI $\alpha$ was detected in the human trigeminal ganglion, the functional identification of neuronal FceRI $\alpha$ in humans and its changes under allergic conditions could be further studied. The application of humanized mice containing the human FceRI receptor would also enhance the clinical significance of this study.

The regulatory mechanism of FceRIa has been researched in immune cells which was involved in multiple factors and mechanisms. IgE was found to upregulate FceRI $\alpha$ even under the condition of blocking synthesis of protein in basophils, which might result from decreased internalization and degradation of membranal FceRI $\alpha$ [44-48]. However, FceRI $\alpha$ localized in endolysosomes of DCs and was responsible for the clearance of IgE by internalization [49]. Cytokines such as IL-3 and TGF- $\beta$ also regulated the expression of FceRI $\alpha$ by affecting the transcription in immune cells $[50,51]$. In our previous study, elevated mRNA and protein of FceRI $\alpha$ in TG was also observed in allergic conjunctivitis model [25]. Given the complex changes in pathology and molecule induced by challenge, we used the allergic conjunctivitis model receiving incremental sensitization without challenge and dissociated neurons cultured with IgE to specifically research the effect of IgE in neuronal FceRI $\alpha$ expression. The results demonstrated that IgE could upregulate neuronal FceRI $\alpha$ without affecting transcription and translation and enhance the neuronal reaction to IgE-immune complex. This suggested that sensory neuron shared the similar regulatory mechanism of FceRI $\alpha$ in basophils. The combination of IgE with membranal FceRIa in sensory neuron might decrease its internalization and degradation. However, these results were not direct evidence for the above mechanism as the increase of membranal FceRI $\alpha$ by IgE was still not certified. This issue could be further investigated by specifically labeling membranal FceRI $\alpha$ in following studies. Overall, IgE not only sensitized the immune cells to be more sensitive to allergen, as well as the peripheral sensory neurons. These results illuminated the regulation mechanism of neuronal FceRI $\alpha$ by IgE and may suggest therapeutic strategies targeting peripheral sensory neurons for itch.

Our findings revealed a novel mechanism of allergic ocular itch via direct activation of FceRI in conjunctiva-innervating sensors by IgE-IC. The FceRI receptor located in sensory neurons and immune cells may work together to contribute to ocular itch accompanying $\mathrm{ACJ}$ in mice and humans by directly activating itchy sensors and/or indirectly stimulating immune cells to induce the release of inflammatory mediators that target primary sensory neurons.

\section{Conclusions}

This study demonstrates that FceRI $\alpha$ in sensory neurons innervating conjunctiva directly mediates IgE-IC induced acute ocular itch. Furthermore, ACJ upregulates FceRI $\alpha$ in sensory neurons innervating conjunctiva, which mediates ACJ-related ocular itch as antigen exposure. In addition, IgE upregulates FceRI $\alpha$ protein in sensory neurons and enhances neuronal responses to IgE-IC. Incremental sensitization would intensity ocular itch as antigen exposure, which might result from upregulated Fc $R$ RI $\alpha$ protein in sensory neurons. These findings reveal a novel neuroimmune axis in allergic itch condition, which highlights the immunosensory capabilities of the itchy neurons.

\section{Abbreviations}

AAV: Adeno-associated virus; ACJ: Allergic conjunctivitis; CGRP: Calcitonin gene-related peptide; DRG: Dorsal root ganglion; FcyRI: Fc-gamma-receptor I; FceRI: FC-epsilon receptor I; His: Histamine; IB4: Isolectin B4; IC: Immune complex; IgE: Immunoglobulin E; IgG: Immunoglobulin G; ITAMs: Immunoreceptor tyrosine-based activation motifs; OVA: Ovalbumin; PAFR: Platelet activating factor receptor; TG: Trigeminal ganglion.

\section{Supplementary Information}

The online version contains supplementary material available at https://doi. org/10.1186/s12974-022-02417-x.

Additional file 1: Figure S1. Expression of FceRla in MrgprA3 ${ }^{+}$pruriceptors. A, B Expression of FceRla in trigeminal ganglion (A) and spleen (B) of FcER/a ${ }^{-/-}$mice. Scale bar: $50 \mu \mathrm{m}$. C Immunostaining by isotype lgG in the TG of WT mice. Scale bar: $50 \mu \mathrm{m}$. D Detection of FcERla by immunostaining in the TG of Mrgpra3 ${ }^{\text {GFP-cre }}$ mice. Scale bar: $100 \mu \mathrm{m}$. E Proportion of FceRla $^{+}$neurons among Mrgpra ${ }^{+}$pruriceptors. F-H Detection of FceRla by immunostaining in the conjunctiva of Mrgpra3 ${ }^{\text {GFP-Cre }} ;$ ROSA26 ${ }^{\text {tdTomato }}$ mice. Scale bar: $20 \mu \mathrm{m}$. Figure S2. IgE-IC directly activates MrgprA3 ${ }^{+}$ pruriceptors in vitro. A Identification of $\mathrm{MrgprA3}^{+}$trigeminal neuron by fluorescent view. B-D Representative fluorescent view and Fura-2 ratiometric imaging of dissociated $\mathrm{MrgprA3}^{+}$neuron (red arrow) and MrgprA3 $^{-}$neuron (white arrow). Scale bar $=50 \mu \mathrm{m}$. Figure S3. IgE-IC does not cause immune cell infiltration in mouse TG. A Mice were ocular instilled with IgE-IC $(1,10,50 \mu \mathrm{g} / \mathrm{ml} ; 5 \mu \mathrm{l})$, monomeric $\operatorname{lgE}(50 \mu \mathrm{g} / \mathrm{ml} ; 5 \mu \mathrm{l})$, OVA $(100 \mathrm{mg} / \mathrm{ml}, 5 \mu \mathrm{l})$ or vehicle (PBS; $5 \mu \mathrm{l})$, and eye-towards wiping bouts were counted over $1-12 \mathrm{~h}$. The baseline was identified as recorded without any instillation. $n=8-10$ mice per group; 2-way ANOVA for repeated measures followed by Bonferroni's post hoc test. B-D Representative images of trigeminal ganglions which were taken $1 \mathrm{~h}$ after ocular instillation with either PBS, monomeric $\lg \mathrm{E}$, or $\lg \mathrm{E}-\mathrm{IC}$ and stained for $\mathrm{Ly} 6 \mathrm{C} / \mathrm{G}$, $\mid \mathrm{BA} 1$, and CD3. Scale bar: $100 \mu \mathrm{m}$. E Quantification showed no significant differences in fluorescence intensity of markers among treatment groups. $n=4$ per group; one-way ANOVA followed by Bonferroni's post hoc test comparisons. F Representative images of trigeminal ganglions which were taken $1 \mathrm{~h}$ after ocular instillation with either PBS, monomeric IgE, or IgE-IC and stained for FITC-avidin. Scale bar: $100 \mu \mathrm{m}$. G Quantitative analysis of mast cells number in the TG after different treatments. $n=4$ per group; one-way ANOVA followed by Bonferroni's post hoc test comparisons. $\mathbf{H}$ Proportions of activated mast cells (with degranulation) in TG after different treatments. $n=4$ per group; one-way ANOVA followed by Bonferroni's post hoc test comparisons. Figure S4. ACJ does not cause immune cell infiltration in mouse TG. A Representative images of mouse TG sections 
stained for Ly6C/G (green) and PGP9.5 (red) $12 \mathrm{~h}$ after ACJ induction or control-treated mice. B Quantification showed no significant difference in fluorescence intensity of Ly6C/G between ACJ and control-treated mice. $n=4$ mice per group; n.s. no significance, Student's $t$-test. C Representative images of mouse TG sections stained for IBA1 (green) and PGP9.5 (red) $12 \mathrm{~h}$ after ACJ induction or control-treated mice. D Quantification showed no significant difference in fluorescence intensity of IBA1 between AC and control-treated mice. $n=4$ mice per group; n.s. no significance, Student's $t$-test. E Representative images of mouse TG sections stained for CD3 (green) and PGP9.5 (red) $12 \mathrm{~h}$ after ACJ induction or control-treated mice. $\mathbf{F}$ Quantification showed no significant difference in fluorescence intensity of $\mathrm{CD} 3$ between $\mathrm{ACJ}$ and control-treated mice. $n=4$ mice per group; $n$.s. no significance, Student's $t$-test. G Representative images of mouse TG sections stained for FITC-avidin (green) and PGP9.5 (red) $12 \mathrm{~h}$ after ACJ induction or control-treated mice. $\mathbf{H}$ Quantitative analysis of mast cells number in TG from ACJ mice or control-treated mice. $n=4$ per group. n.s. no significance, Student's t-test. I Proportions of activated mast cells (with degranulation) in TG from ACJ mice or control-treated mice. $n=4$ per group. n.s. no significance, Student's $t$-test. Figure S5. Contribution of neuronal FceRla in conjunctival inflammation at 12th hour following ACJ. Representative conjunctiva sections from mice infected by AAV9Pirt-NC-EGFP or AAV9-Pirt-shFceRla-EGFP after OVA challenge and stained for Ly6C/G (A), IBA1 (C), and CD3 (E). Scale bar, $100 \mu \mathrm{m}$. The embedded boxes showed the enlarged views. B Quantification for fluorescence intensity of Ly6C/G showed no significant differences as comparing Control- or ACJ-treated mice between two viruses' groups (Left). Quantitative analysis of Ly6C/G+ cell numbers showed no significant differences as comparing Control- or ACJ-treated mice between two viruses' groups (Right). $n=4$ per group; Student's $t$-test. D Quantification for fluorescence intensity of IBA1 showed no significant differences as comparing Control- or ACJtreated mice between two viruses' groups (Left). Quantitative analysis of $\mid B A 1+$ cell numbers showed no significant differences as comparing Control- or ACJ-treated mice between two viruses' groups (Right). $n=4$ per group; Student's t-test. F Quantification for fluorescence intensity of CD3 showed no significant differences as comparing Control- or ACJ-treated mice between two viruses' groups (Left). Quantitative analysis of CD3+ cell numbers showed no significant differences as comparing Control- or ACJ-treated mice between two viruses' groups (Right). $n=4$ per group; Student's $t$-test. n.s. no significance, AAV9-Pirt-NC-EGFP vs. AAV9-PirtshFcERla-EGFP. Figure S6. IgE enhances $\mathrm{Ca}^{2+}$ response of MrgprA3 ${ }^{+}$ trigeminal neurons to $\lg \mathrm{E}-\mathrm{IC}$. A The percentage of $\mathrm{IgE}-\mathrm{IC}(0.1 \mathrm{\mu g} / \mathrm{ml})$ responsive $\mathrm{MrgprA3}^{+}$neurons was significantly increased as cultured with $\lg \mathrm{E}(5 \mu \mathrm{g} / \mathrm{ml}) .{ }^{*} P<0.05$, lgE vs. Control, $X^{2}$ test. B Magnitude of lgE-ICevoked $\mathrm{Ca}^{2+}$ responses was significantly increased for MrgprA3 ${ }^{+}$neurons cultured with lgE $(5 \mu \mathrm{g} / \mathrm{ml})$ in MrgPra3 ${ }^{G F P-C r e}$ mice. ${ }^{*} P<0.05$, IgE vs. Control, Student's t-test. Figure $\mathbf{S 7}$. Incremental sensitization gradually upregulates trigeminal FceRla in small-diameter neurons. A Schematic diagram of experimental design for incremental sensitization model. B Determination of anti-OVA IgE in the serum of each group. ${ }^{*} P<0.05$, vs. Control, one-way ANOVA followed by Bonferroni's post hoc test comparisons. CTypical images for the immunofluorescence staining of FceRla (green) and PGP9.5 (red) in the Control, Sensitized 1w, Sensitized $2 \mathrm{w}$ and Sensitized $3 \mathrm{w}$ mice. Scale bar: $25 \mu \mathrm{m}$. D Percentage of FceRla-immunopositive TG neurons from mice receiving sensitization of different times ( $n>100$ neurons total for each group). ${ }^{*} P<0.05$, vs. Control; ${ }^{\#} P<0.05$, vs. sensitized $1 w, X^{2}$ test.

Additional file 2: Table S1. List of antibodies. List of antibodies for IF.

\section{Acknowledgements}

We thank Dr. Wenyin Qiu, Dr. Xiaojing Qian, and Dr. Yongmei Chen in the Department of Anatomy, Histology and Embryology, Institute of Basic Medical Sciences Chinese Academy of Medical Sciences for their technical assistance in immunohistochemistry.

\section{Authors' contributions}

$\mathrm{HC}$ and $\mathrm{FL}$ drafted the manuscript. $\mathrm{HC}$ performed the immunofluorescence staining, Western blotting and behavioral test. FL and YF performed the ACJ model and behavioral assessment. TW and BY performed the data analysis. CM conceived of the study, participated in its design, and helped to draft the manuscript. All authors read and approved the final manuscript.

\section{Funding}

This work was supported by grants from the National Natural Science Foundation of China [\#81771205 (Chao Ma) and \#81801114 (Fan Liu)].

\section{Availability of data and materials}

There are no data, software, databases, and application/tools available apart from those reported in the present study. All data are provided in the manuscript and Additional files 1, 2.

\section{Declarations}

\section{Ethics approval and consent to participate}

All animal procedures performed in this study were reviewed and approved by the Institutional Animal Care and Use Committee of the Institute of Basic Medical Sciences, Chinese Academy of Medical Sciences, Peking Union Medical College (Beijing, China) and were conducted in accordance with the guidelines of the International Association for the Study of Pain.

\section{Consent for publication}

Not applicable.

\section{Competing interests}

The authors declare that they have no competing interests.

\section{Author details}

${ }^{1}$ Department of Human Anatomy, Histology and Embryology, Institute of Basic Medical Sciences, Neuroscience Center, Chinese Academy of Medical Sciences, School of Basic Medicine, Peking Union Medical College, Beijing, China. ${ }^{2}$ National Human Brain Bank for Development and Function, Institute of Basic Medical Sciences Chinese Academy of Medical Sciences, School of Basic Medicine Peking Union Medical College, Beijing, China. ${ }^{3}$ Chinese Institute for Brain Research, Beijing, China.

Accepted: 15 February 2022

Published online: 23 February 2022

\section{References}

1. Rosario N, Bielory L. Epidemiology of allergic conjunctivitis. Curr Opin Allergy Clin Immunol. 2011;11:471-6.

2. Ono SJ, Abelson MB. Allergic conjunctivitis: update on pathophysiology and prospects for future treatment. J Allergy Clin Immunol. 2005;115:118-22.

3. Fukuda K, Ohbayashi M, Morohoshi K, Zhang L, Liu F-T, Ono SJ. Critical role of IgE-dependent mast cell activation in a murine model of allergic conjunctivitis. J Allergy Clin Immunol. 2009;124:827-833.e822.

4. Dong $X$, Dong $X$. Peripheral and central mechanisms of itch. Neuron. 2018;98:482-94.

5. Liu Q, Dong X. The role of the Mrgpr receptor family in itch. Handb Exp Pharmacol. 2015;226:71-88.

6. LaMotte $\mathrm{RH}$, Dong $X$, Ringkamp M. Sensory neurons and circuits mediating itch. Nat Rev Neurosci. 2014;15:19-31.

7. Zhao J, Munanairi A, Liu XY, Zhang J, Hu L, Hu M, Bu D, Liu L, Xie Z, Kim BS, et al. PAR2 mediates itch via TRPV3 signaling in keratinocytes. J Invest Dermatol. 2020;140:1524-32.

8. Simons FE, Simons KJ. Histamine and H1-antihistamines: celebrating a century of progress. J Allergy Clin Immunol. 2011;128:1139-1150.e1134.

9. Bielory L. Ocular allergy treatment. Immunol Allergy Clin North Am. 2008;28(189-224):vii.

10. Amirian ES, Marquez-Do D, Bondy ML, Scheurer ME. Antihistamine use and immunoglobulin E levels in glioma risk and prognosis. Cancer Epidemiol. 2013;37:908-12.

11. Yamana Y, Fukuda K, Ko R, Uchio E. Local allergic conjunctivitis: a phenotype of allergic conjunctivitis. Int Ophthalmol. 2019;39:2539-44.

12. Mimura T, Yamagami S, Kamei Y, Goto M, Matsubara M. Specific IgE in tear fluid and features of allergic conjunctivitis. Curr Eye Res. 2013;38:917-25.

13. Jensen RK, Jabs F, Miehe M, Mølgaard B, Pfützner W, Möbs C, Spillner E, Andersen GR. Structure of intact IgE and the mechanism of ligelizumab revealed by electron microscopy. Allergy. 2020;75:1956-65. 
14. Corry DB, Kheradmand F. Induction and regulation of the IgE response. Nature. 1999:402:B18-23.

15. Turner $\mathrm{H}$, Kinet JP. Signalling through the high-affinity IgE receptor $\mathrm{FC}$ epsilonRI. Nature. 1999;402:B24-30.

16. Siraganian RP. Mast cell signal transduction from the high-affinity lgE receptor. Curr Opin Immunol. 2003;15:639-46.

17. Gounni AS, Lamkhioued B, Delaporte E, Dubost A, Kinet JP, Capron A, Capron M. The high-affinity IgE receptor on eosinophils: from allergy to parasites or from parasites to allergy? J Allergy Clin Immunol. 1994;94:1214-6.

18. Alber $\mathrm{G}$, Kent UM, Metzger H. Functional comparison of Fc epsiIon RI, Fc gamma RIl, and Fc gamma RIII in mast cells. J Immunol. 1992;149:2428-36.

19. Garman SC, Kinet JP, Jardetzky TS. Crystal structure of the human highaffinity lgE receptor. Cell. 1998;95:951-61.

20. Garman SC, Wurzburg BA, Tarchevskaya SS, Kinet JP, Jardetzky TS. Structure of the Fc fragment of human IgE bound to its high-affinity receptor Fc epsilonRI alpha. Nature. 2000;406:259-66.

21. Gevaert P, Omachi TA, Corren J, Mullol J, Han J, Lee SE, Kaufman D, Ligueros-Saylan M, Howard M, Zhu R, et al. Efficacy and safety of omalizumab in nasal polyposis: 2 randomized phase 3 trials. J Allergy Clin Immunol. 2020;146:595-605.

22. Heffler E, Picardi G, Liuzzo MT, Pistorio MP, Crimi N. Omalizumab treatment of vernal keratoconjunctivitis. JAMA Ophthalmol. 2016;134:461-3.

23. van der Kleij H, Charles N, Karimi K, Mao YK, Foster J, Janssen L, Chang Yang P, Kunze W, Rivera J, Bienenstock J. Evidence for neuronal expression of functional Fc (epsilon and gamma) receptors. J Allergy Clin Immunol. 2010;125:757-60.

24. Andoh T, Kuraishi Y. Expression of Fc epsilon receptor I on primary sensory neurons in mice. NeuroReport. 2004;15:2029-31.

25. Liu F, Xu L, Chen N, Zhou M, Li C, Yang Q, Xie Y, Huang Y, Ma C. Neuronal Fc-epsilon receptor I contributes to antigen-evoked pruritus in a murine model of ocular allergy. Brain Behav Immun. 2017:61:165-75.

26. Liu Q, Tang Z, Surdenikova L, Kim S, Patel KN, Kim A, Ru F, Guan Y, Weng $H J$, Geng Y, et al. Sensory neuron-specific GPCR Mrgprs are itch receptors mediating chloroquine-induced pruritus. Cell. 2009;139:1353-65.

27. Han L, Ma C, Liu Q, Weng HJ, Cui Y, Tang Z, Kim Y, Nie H, Qu L, Patel KN, et al. A subpopulation of nociceptors specifically linked to itch. Nat Neurosci. 2013;16:174-82.

28. Zhao H, Yang H, Geng C, Chen Y, Pang J, Shu T, Zhao M, Tang Y, Li Z, Li B, et al. Role of IgE-FceR1 in pathological cardiac remodeling and dysfunction. Circulation. 2021:143:1014-30.

29. Huang CC, Yang W, Guo C, Jiang H, Li F, Xiao M, Davidson S, Yu G, Duan B, Huang T, et al. Anatomical and functional dichotomy of ocular itch and pain. Nat Med. 2018;24:1268-76.

30. Huang CC, Kim YS, Olson WP, Li F, Guo C, Luo W, Huang AJW, Liu Q. A histamine-independent itch pathway is required for allergic ocular itch. J Allergy Clin Immunol. 2016;137:1267-1270.e1266.

31. Zhang Q, Cao DL, Zhang ZJ, Jiang BC, Gao YJ. Chemokine CXCL13 mediates orofacial neuropathic pain via CXCR5/ERK pathway in the trigeminal ganglion of mice. J Neuroinflamm. 2016;13:183.

32. Su W, Yu J, Zhang $X, M a L$, Huang Y. Proteome profile of trigeminal ganglion in murine model of allergic contact dermatitis: complement 3 pathway contributes to itch and pain sensation. Neurotox Res. 2021. https://doi.org/10.1007/s12640-021-00384-4

33. Jiang H, Cui H, Wang T, Shimada SG, Sun R, Tan Z, Ma C, LaMotte RH. CCL2/CCR2 signaling elicits itch- and pain-like behavior in a murine model of allergic contact dermatitis. Brain Behav Immun. 2019;80:464-73.

34. Kubo M. Mast cells and basophils in allergic inflammation. Curr Opin Immunol. 2018:54:74-9.

35. Boyce JA. Mast cells: beyond IgE. J Allergy Clin Immunol. 2003;111:24-32 (quiz 33).

36. Pall PS, Hurwitz OE, King BA, LaMotte RH. Psychophysical measurements of itch and nociceptive sensations in an experimental model of allergic contact dermatitis. J Pain. 2015;16:741-9.

37. Leuchtweis J, Segond von Banchet G, Eitner A, Ebbinghaus M, Schaible HG. Pain-related behaviors associated with persistence of mechanical hyperalgesia after antigen-induced arthritis in rats. Pain. 2020;161:1571-83.
38. Jiang H, Shen X, Chen Z, Liu F, Wang T, Xie Y, Ma C. Nociceptive neuronal $\mathrm{Fc}$-gamma receptor I is involved in Ig $\mathrm{G}$ immune complex induced pain in the rat. Brain Behav Immun. 2017:62:351-61.

39. Liu F, Shen X, Su S, Cui H, Fang Y, Wang T, Zhang L, Huang Y, Ma C. Fcy receptor I-coupled signaling in peripheral nociceptors mediates joint pain in a rat model of rheumatoid arthritis. Arthritis Rheumatol. 2020;72:1668-78.

40. Wang L, Jiang X, Zheng Q, Jeon SM, Chen T, Liu Y, Kulaga H, Reed R, Dong $X$, Caterina MJ, Qu L. Neuronal FcyRI mediates acute and chronic joint pain. J Clin Invest. 2019;129:3754-69.

41. McCoy ES, Taylor-Blake B, Street SE, Pribisko AL, Zheng J, Zylka MJ. Peptidergic CGRPa primary sensory neurons encode heat and itch and tonically suppress sensitivity to cold. Neuron. 2013;78:138-51.

42. Sanchez-Miranda E, Ibarra-Sanchez A, Gonzalez-Espinosa C. Fyn kinase controls FcepsilonRI receptor-operated calcium entry necessary for full degranulation in mast cells. Biochem Biophys Res Commun. 2010;391:1714-20.

43. Qu L, Li Y, Pan X, Zhang P, LaMotte RH, Ma C. Transient receptor potential canonical 3 (TRPC3) is required for lgG immune complex-induced excitation of the rat dorsal root ganglion neurons. J Neurosci. 2012;32:9554.

44. Furuichi K, Rivera J, Isersky C. The receptor for immunoglobulin E on rat basophilic leukemia cells: effect of ligand binding on receptor expression. Proc Natl Acad Sci USA. 1985;82:1522-5.

45. MacGlashan D Jr. IgE receptor and signal transduction in mast cells and basophils. Curr Opin Immunol. 2008;20:717-23.

46. MacGlashan D Jr, Xia HZ, Schwartz LB, Gong J. IgE-regulated loss, not IgE-regulated synthesis, controls expression of FcepsilonRl in human basophils. J Leukoc Biol. 2001;70:207-18.

47. Conner ER, Saini SS. The immunoglobulin E receptor: expression and regulation. Curr Allergy Asthma Rep. 2005;5:191-6.

48. Kubo S, Matsuoka K, Taya C, Kitamura F, Takai T, Yonekawa H, Karasuyama H. Drastic up-regulation of Fcepsilonri on mast cells is induced by lgE binding through stabilization and accumulation of Fcepsilonri on the cell surface. J Immunol. 2001;167:3427-34.

49. Greer AM, Wu N, Putnam AL, Woodruff PG, Wolters P, Kinet JP, Shin JS. Serum IgE clearance is facilitated by human FceRl internalization. J Clin Invest. 2014;124:1187-98.

50. Zellweger F, Buschor P, Hobi G, Brigger D, Dahinden CA, Villiger PM, Eggel A. IL-3 but not monomeric lgE regulates FceRl levels and cell survival in primary human basophils. Cell Death Dis. 2018;9:510.

51. Yamazaki S, Nakano N, Honjo A, Hara M, Maeda K, Nishiyama C, Kitaura J, Ohtsuka Y, Okumura K, Ogawa H, Shimizu T. The transcription factor Ehf is involved in TGF- $\beta$-induced suppression of FceRl and c-Kit expression and FceRI-mediated activation in mast cells. J Immunol. 2015;195:3427-35.

\section{Publisher's Note}

Springer Nature remains neutral with regard to jurisdictional claims in published maps and institutional affiliations.

Ready to submit your research? Choose BMC and benefit from:

- fast, convenient online submission

- thorough peer review by experienced researchers in your field

- rapid publication on acceptance

- support for research data, including large and complex data types

- gold Open Access which fosters wider collaboration and increased citations

- maximum visibility for your research: over 100M website views per year

At BMC, research is always in progress.

Learn more biomedcentral.com/submissions 